This item was submitted to Loughborough's Research Repository by the author.

Items in Figshare are protected by copyright, with all rights reserved, unless otherwise indicated.

\title{
Service recovery in higher education: does national culture play a role?
}

PLEASE CITE THE PUBLISHED VERSION

http://dx.doi.org/10.1080/0267257X.2011.609133

\section{PUBLISHER}

Taylor \& Francis / @ Westburn Publishers Ltd.

\section{VERSION}

AM (Accepted Manuscript)

\section{LICENCE}

CC BY-NC-ND 4.0

\section{REPOSITORY RECORD}

Gruber, Thorsten, IIma Nur Chowdhury, and Alexander E. Reppel. 2019. "Service Recovery in Higher Education: Does National Culture Play a Role?”. figshare. https://hdl.handle.net/2134/11924. 
This item was submitted to Loughborough's Institutional Repository (https://dspace.lboro.ac.uk/) by the author and is made available under the following Creative Commons Licence conditions.

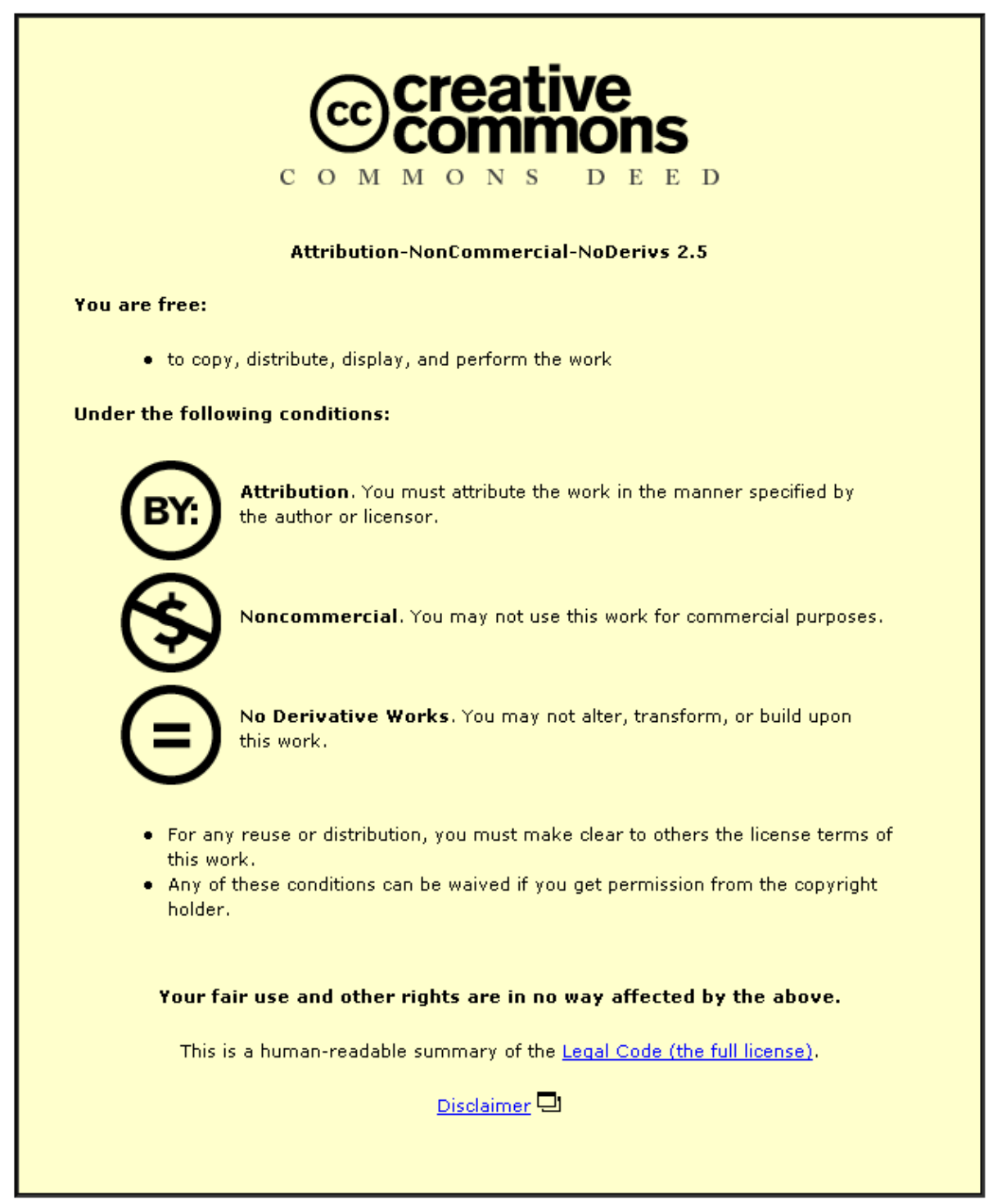

For the full text of this licence, please go to: http://creativecommons.org/licenses/by-nc-nd/2.5/ 


\title{
Service Recovery in Higher Education: Does National Culture Play a Role?
}

\author{
Thorsten Gruber* \\ The University of Manchester, Manchester Business School, \\ Booth Street West, Manchester M15 6PB, UK \\ Tel.: +44-(0)161-275 6479 \\ Email: thorsten.gruber@mbs.ac.uk \\ Ilma Nur Chowdhury \\ The University of Manchester, Manchester Business School, \\ Booth Street West, Manchester M15 6PB, UK \\ Tel.: +44-(0)161-275 6479 \\ Email: ilma.chowdhury@ postgrad.mbs.ac.uk
}

\author{
Alexander Reppel \\ Royal Holloway, University of London, \\ School of Management \\ Egham Hill, Egham \\ Surrey TW20 0EX \\ Phone: +4401784 276117 \\ Email: alexander.reppel@rhul.ac.uk
}

Re-Re-Re-Submitted for Review

Journal of Marketing Management

July 2011

*=Corresponding author 


\section{Biography}

Thorsten Gruber is a Senior Lecturer in Marketing and Service Management in the Manchester Business School, University of Manchester. Prior to that, he was engaged in postdoctoral research at the Birmingham Business School, University of Birmingham and a part-time visiting lecturer at the University of Education Ludwigsburg. He received his Ph.D. and MBA from the University of Birmingham. His research interests include consumer complaining behaviour, services marketing and the development of qualitative online research methods. His work has been published and/or is forthcoming in journals such as Journal of the Academy of Marketing Science, Journal of Business Research, Industrial Marketing Management, Journal of Marketing Management, Journal of Services Marketing, Journal of Service Management, International Journal of Public Sector Management, Journal of Business and Industrial Marketing, Qualitative Market Research, Journal of Product and Brand Management, Managing Service Quality, Journal of Marketing for Higher Education, International Journal of Educational Management, Journal for Quality Assurance in Education, The TQM Journal, and Management Services.

Contact: The University of Manchester, Manchester Business School, Booth Street West, Manchester M15 6PB, UK, Tel.: +44-(0)161-275 6479

Email: thorsten.gruber@mbs.ac.uk

Ilma Nur Chowdhury is a Doctoral Candidate and Researcher at Manchester Business School, University of Manchester. After having successfully completed her Master's degree (MSc Marketing) with distinction at Manchester Business School, Ilma worked as a Research Associate at North South University in Dhaka, Bangladesh and as a Lecturer at the Institute of Business Administration, University of Dhaka. She returned to the UK for doctoral study on full scholarship. Her research interests lie in services marketing and business-to-business marketing.

Contact: The University of Manchester, Manchester Business School, Booth Street West, Manchester M15 6PB, UK, Tel.: +44-(0)161-275 6479

Email: ilma.chowdhury@postgrad.mbs.ac.uk

Alexander E. Reppel is a Senior Lecturer in Marketing at Royal Holloway, University of London. His main research interests are in relationship marketing in consumer markets, marketing ethics, and consumer data management practices. Alexander is also involved in the development of innovative online research methods, such as interviewer- and non-interviewer-based online laddering techniques. He has published in journals such as the European Journal of Marketing, Industrial Marketing Management, Journal of Marketing Management, International Journal of Service Industry Management, Journal of Business and Industrial Marketing, Journal of Marketing for Higher Education, International Journal of Educational Management, Qualitative Market Research, The TQM Journal, and the Journal of Product \& Brand Management, among others. Contact: Royal Holloway, University of London, Egham, Surrey, TW20 0EX, UK, Tel.: +44 (0) 1784276117

Email: alexander.reppel@rhul.ac.uk 


\title{
Service Recovery in Higher Education - Does National Culture Play a Role?
}

\begin{abstract}
It is now well recognised that an effective service recovery system plays a crucial role in service organisations. However, the importance of such systems has not yet been acknowledged by the higher education industry. Given the need for more research on service recovery expectations of students, this exploratory study attempts to shed light on what students believe to be the desirable attributes of professors during recovery encounters. To investigate how national culture influences student expectations during such encounters, 40 students from the United Kingdom and Bangladesh were interviewed and 210 questionnaires were completed by students. Using the semi-standardised laddering interviewing technique in combination with Kano questionnaires, the study provides an indepth insight into the qualities and behaviours that students expect professors to portray during service recovery encounters. The research reveals that the key attributes desired by both groups of students include being approachable, listening actively, showing empathy and providing an explanation. Among a wide range of benefits, students link these attributes to enhanced teacher-student relationship, better academic performance and at a more abstract level, to desired end-states such as harmony and wellbeing.
\end{abstract}

Keywords Service failure and recovery, educational services, laddering, Kano, cultural differences 


\section{Service Recovery in Higher Education - Does National Culture Play a Role?}

\section{Introduction}

Service providers are frequently exhorted to strive towards a "zero defects" service because the ability to 'do it right the first time' offers significant benefits in terms of positive customer evaluations and lower costs of delivery (Hart, Heskett \& Sasser, 1990; Zeithaml, Bitner \& Gremler, 2006). However, it is unrealistic to assume that such a goal can always be attained (Schoefer \& Diamantopoulos, 2008), due to the inherent heterogeneity in service provision and limitations on the extent to which a provider can control the range of different interactions with customers (Zeithaml et al., 2006). Moreover, real or perceived failures in the service system are inevitable because most services are characterised by simultaneous production and consumption as well as involvement by customers in the service production (Hart et al., 1990).

In the case of a service failure, companies have to make an effort to correct the problem in order to recover profitable customers. Zemke and Bell (1990) define service recovery as a planned process for returning aggrieved customers to a state of satisfaction with the organisation, after a service has failed to live up to expectations. Complaint management is part of service recovery, however service recovery also embraces proactive efforts to solve problems at the service encounter even before customers complain (Michel, 2001). Considering that research shows that only about 5 to $10 \%$ of dissatisfied customers actually complain (Tax \& Brown, 1998), developing a strategy for service recovery is particularly important to deal with service failures effectively, as well as to encourage the voicing of complaints.

There is strong evidence for the positive impact of service recovery on consumer satisfaction, word-of-mouth, repurchase intentions and overall evaluation of the service quality (e.g. Mattila, 2001). On the other hand, poor recovery attempts intensify the negative effects of service failures, such as negative word-of-mouth and switching behaviour (Blodgett, Hill \& Tax, 1997). 


\section{Service failure and recovery in higher education}

A service industry that can greatly benefit from the application of marketing principles in the area of service recovery is higher education (Iyer \& Muncy, 2008). According to authors such as Curran and Rosen (2006), higher education can be regarded as a service industry and Frankel and Swanson (2002) point to the similarities between education and services in their delivery and evaluation processes. Thus, findings from the services literature should be applicable to the context of higher education in general and to (critical) student-professor service encounters in particular. Moreover, Iyer and Muncy (2008) have recently used concepts from services marketing research to investigate services failures within a classroom setting.

Following Hemsley-Brown and Oplatka (2006), we believe that there is a demand for more research that explores the application of services marketing concepts to the higher education service industry. Previous research has focused on the application of marketing principles to higher education in areas such as branding (Hemsley-Brown \& Goonawardana, 2007; Lowrie, 2007), student recruitment and decision-making (Cubillo, Sanchez \& Cervino, 2006; Maringe, 2005), the marketing mix in higher education (Bingham, 1987; Stewart, 1991), student retention and relationship management (Helgesen, 2008; Armstrong, 2003), international education marketing (Cubillo et al., 2006; Mazzarol, Soutar \& Seng, 2003), student services quality and satisfaction (Abdullah, 2006; Athiyaman, 1997; Ivy, 2001) and student satisfaction guarantees (Gremler \& McCollough, 2002).

Service failures are common in academic settings (Iyer \& Muncy, 2008; Swanson \& Davis, 2000). Examples of service failures include the professor not coming to class or not being available during posted office hours, ambiguous exam questions, grading errors and refusal to respond to student questions related to course material (Frankel, Swanson \& Sagan, 2006; Iyer \& Muncy, 2008). For failures in the educational delivery system, Frankel et al. (2006) found that the professor's response to student disappointments is what causes the student to remember the event either positively or 
negatively. Thus, it would be beneficial for educational institutions and particularly professors to understand how they can effectively recover from experienced service failures (Swanson \& Davis, 2000).

Despite this, extant literature offers surprisingly little guidance about what student expectations are regarding professors' qualities and behaviours during these 'critical moments of truth'. Moreover, Corbyn (2009) reports that universities as service providers are still complacent when it comes to learning from students' problems. Recently, the Office of the Independent Adjudicator has also noted a $20 \%$ rise in student complaints in the UK (Corbyn, 2009). It is thus more important than ever for higher education institutions to develop appropriate service recovery strategies. Moreover, Davis and Swanson's (2001) findings indicate that students who experience service failures in the classroom demonstrate a strong propensity to share negative information about their experience. They point out that, since students today have the opportunity to communicate with an unlimited number of others via the internet, by not recovering from failures professors risk having their reputation damaged. Davis and Swanson (2001) also suggest that students often do not direct complaints to educators, sometimes due to fear of reprisals (Mukherjee, Pinto \& Malhotra, 2009). This deprives professors from acquiring valuable feedback regarding their performance and makes it difficult to make potentially important improvements (Davis \& Swanson, 2001). In the higher education industry today, there is fierce competition for funds, students and the revenue they generate (Hwarng \& Teo, 2001). The increasing focus paid to teaching quality, student evaluations and student satisfaction guarantees makes understanding student expectations and (dis)satisfaction particularly important to professors (McCollough \& Gremler, 1999). Therefore, both higher education institutions and professors should be interested in understanding how to respond when students are dissatisfied and attempt to move them towards voice behaviour (Mukherjee et al., 2009) by having a good recovery system in place. Service recovery is also one of the central tenets of the relationship marketing approach (Tax, Brown \& 
Chandrashekaran, 1998) and recently Helgesen (2008) pointed out that relationship marketing is crucial for universities keen to increase student enrolment and retention.

\section{The role of professors in service recovery encounters in higher education}

The effectiveness of service recovery depends greatly on how employees handle the problem (Bitner, Booms \& Tetreault, 1990). Browne, Kaldenberg, Browne \& Brown (1998) conclude that the likelihood of students recommending the university to friends/relatives is particularly influenced by interactions between students and university personnel, such as their faculty. Frankel et al. (2006) and Iyer and Muncy (2008) found that the professor's response to service failures is the key factor in determining student satisfaction. It is thus clear that the role of the professor is crucial during recovery encounters. Professors are in a more advantageous position than service employees in other consumer service industries, as they have greater discretion in carrying out the tasks they perceive as appropriate to meet student expectations (Swanson \& Davis, 2000). However, to better understand students, professors need to be aware of how students expect them to behave in such encounters (Swanson \& Davis, 2000). Knowledge of student expectations during service recovery thus holds important implications, not only for education institutions but also for professors because students who are satisfied with the service recovery are likely to attend another lecture delivered by the same professor or opt for another course taught by her/him and recommend it to other students (Banwet \& Datta, 2003).

Therefore, this study focuses on exploring the desired qualities and behaviours of professors during service recovery encounters. Professors are the "contact personnel" associated with the core service and for universities the core service is still the lecture (Sohail \& Shaikh, 2004, p. 63). Moreover, emphasis will be placed on face-to-face service recovery encounters, with these inevitably occurring most frequently in the higher education context due to the interactive nature of the service, with research also 
indicating that consumers prefer interactive rather than remote channels in such situations (Mattila \& Wirtz, 2004).

\section{The influence of national culture on service recovery expectations}

An important gap in the services marketing literature is its applicability in cross-national settings (Mattila \& Patterson, 2004a). It is noted that most research in consumer behaviour relies on theoretical frameworks developed in Western societies (Mattila \& Patterson, 2004b). Hence, relatively little is known about the cross-cultural generalisability of service recovery strategies (Mattila \& Patterson, 2004a). Individual expectations for appropriate social behaviour and communication are, to a large extent, determined by their national culture (Hall, 1976; Hofstede \& Hofstede, 2005). As service recovery encounters involve social exchanges between people, understanding the influence of national culture is crucial to developing effective service recovery strategies (Mattila \& Patterson, 2004b).

Although some attention has been paid to international students' expectations in Western university contexts, research on cross-national comparisons of student expectations is rather limited (Swanson, Frankel \& Sagan, 2005). In particular, what remains to be explored are the expectations of students regarding the qualities and behaviours of professors during service recovery encounters in crossnational settings. In order to address this gap in the literature, the proposed research attempts to study students from two culturally diverse countries (UK and Bangladesh). A greater understanding of how cultural differences affect service recovery expectations of students would allow faculty to identify appropriate practices to deal with service failures (Frankel et al., 2006). The importance of taking into account the influence of national culture is also highlighted by Frankel et al.'s (2006) research, which reports that whilst student-professor encounters that have satisfactory outcomes are perceived similarly by students, encounters with unsatisfactory outcomes are perceived dissimilarly by students from different cultures. 


\section{Objectives of the research study}

This research particularly aims to provide a deeper insight into service recovery expectations in higher education. The internationalisation of higher education has led to a greater number of professors engaging in cross-national careers and there is an increasing number of students from different cultures studying in higher education institutions (Frankel et al., 2006). It is therefore important to understand how culture influences service recovery expectations so that recovery strategies can be tailored accordingly.

In particular, this study aims to identify how professors should behave and which qualities they should possess during face-to-face service recovery encounters. The paper also explores how students perceive the attributes of professors and how satisfied they are with them. For this purpose, the research examines which attributes of professors are likely to cause satisfaction and which dimensions predominately lead to dissatisfaction. Knowing what students regard as satisfactory and dissatisfactory attributes helps professors improve the service recovery experience either by improving interpersonal skills or by just having a better understanding of the student's perspective (Davis \& Swanson, 2001). Similarly, Desai, Damewood and Jones (2001, p. 136) suggest that "the more faculty members know about students, the better they can provide educational services to them". Gained insights can then be used to be more responsive to students during student-professor service recovery encounters without compromising integrity. Second, we explore the constructs that underlie students' service recovery expectations, that is, identifying how the expected behaviours of professors in service recovery encounters are linked to the underlying needs of students. Third, the study also attempts to shed light on the benefits students seek and the values they hold important in higher education settings. Fourth, we want to explore the similarities and differences in service recovery expectations of students from different national cultures. 


\section{Research methods - Laddering interviews and Kano questionnaires}

To gain the desired deeper insight, the established laddering interviewing technique will be used first, followed then by Kano questionnaires. Laddering is generally employed to reveal the relationships which exist between the attributes of products, services or individuals ("means"), the consequences these attributes represent for the respondent, and the personal values or beliefs that are strengthened or satisfied by the consequences (“ends") (Reynolds \& Gutman, 1988). Attributes are the tangible and intangible characteristics of an offering (in our study a complaint resolution). Consequences are the reasons why certain attributes are important to the individual. They are the psychological, physiological or process results that respondents think they can achieve by using the product or service (Gutman, 1982). Values are the individuals' universal life and company goals. They represent the most personal and general consequences that individuals or organisations are striving for (Rokeach, 1973). Consequences are more relevant to the self than attributes and values are in turn more relevant to the self than consequences.

Laddering usually involves semi-standardised personal in-depth interviews, with the interviewer probing to reveal attribute-consequence-value chains (i.e. 'ladders'). The interviewer repeatedly questions why an attribute, a consequence or a value is important to the respondent, with the answer acting as the starting point for further questioning, until saturation is reached. Cognitive concepts gleaned during the laddering interviews and analysis are then summarised in a graphical representation of a set of means-end chains known as a Hierarchical Value Map (HVM). Although predominately used for brand or product positioning issues (Gutman, 1982), laddering has recently been applied successfully to research areas such as relationship marketing (Paul, Hennig-Thurau, Gremler, Gwinner \& Wiertz, 2009), sales management (Deeter-Schmelz, Goebel \& Kennedy, 2008) and services marketing (Gruber, Szmigin \& Voss, 2009). 
While laddering is commonly used in exploratory qualitative phases of research projects (e.g. Botschen, Thelen \& Pieters, 1999; Zanoli \& Naspetti, 2002) as it allows researchers to reveal the "reasons behind the reasons" (Gengler, Mulvey \& Oglethorpe, 1999, p. 175), the Kano methodology reveals which professorial attributes have the strongest impact on the students' (dis)satisfaction with the service recovery. Laddering interviews alone do not provide this important information.

Over almost 30 years, Kano's (1984) model of satisfaction has increasingly gained acceptance and interest from both academics and practitioners (Löfgren \& Witell, 2008). Early work was conducted in the area of engineering (Kano, 1984). More recently, however, the Kano methodology has been applied successfully to diverse domains such as employee satisfaction (Matzler, Bailom, Hinterhuber, Renzl \& Pichler, 2004) and internet community bonding (Szmigin \& Reppel, 2004). The Kano methodology posits that satisfaction is a multidimensional construct consisting of the following categories (Kano, 1984): Must-be quality elements, or basic factors (Matzler et al., 2004) are features that individuals take for granted. The fulfilment of these requirements does not increase satisfaction. If the product or service or behaviour, however, does not meet expectations, then individuals will be very dissatisfied. One-dimensional quality elements, or performance factors, are attributes for which the relationship between attribute performance and (dis)satisfaction is linear. The more or less an attribute fulfils the requirements, the more or less individuals are satisfied. Attractive quality elements, or excitement factors are attributes that make individuals very satisfied or even delighted (Matzler, Hinterhuber, Bailom \& Sauerwein, 1996), if the product or service or behaviour achieves these factors fully. Individuals are, however, not dissatisfied if products or services or behaviours do not meet these requirements. The attributes are classified based on the responses to the Kano questionnaire and can then be visualised in a chart that illustrates which attributes are basic, performance or excitement factors. 


\section{The research study}

It has been considered important to choose culturally diverse countries since this is an exploratory study on how service recovery expectations could vary across national cultures. Moreover, Mattila and Patterson (2004a) have recently expressed the need for service recovery research in West Asian countries such as India and Bangladesh. Zhang, Beatty and Walsh's (2008) review of cross-cultural consumer services research indicates that currently no work has included Bangladesh and only one study (Kanousi, 2005) has included the UK in studying cross-cultural service recovery expectations. Therefore, it is believed that the current study, although industry-specific and exploratory in nature, can contribute to the limited literature on cross-cultural service recovery research. Zhang et al.'s (2008) review also indicates that Hofstede's (2001) five dimensions (power distance, individualism, masculinity, uncertainty avoidance and long term orientation) provide the most popular framework for cross-cultural services research.

Following Hofestede's (2001) framework, the Bangladeshi culture is characterised by collectivism (low individualism) and high power distance, while the UK culture is characterised by high individualism and low power distance. The two countries do not differ as much on the other dimensions. In fact, individualism/collectivism is widely regarded as being the most researched and validated dimension of the framework (Maheswaran \& Shavitt, 2000). These cultural dimensions are also relevant here because both individualism/collectivism and power distance focus on the relationships between oneself and other people. Individualism is the degree to which people's identities are linked to their existence as individuals, rather than as members of groups (Hofstede \& Hofstede, 2005). The power distance dimension refers to the extent to which the less powerful members of institutions and organizations within a country expect and accept that power is distributed unequally (Hofstede \& Hofstede, 2005). The individualism and power distance dimensions are correlated; large power distance countries tend to be more collectivist while small power distance countries tend to be 
more individualist (Hofstede \& Hofstede, 2005). Furthermore, individualist cultures are high-context cultures whereas collectivist ones are low-context cultures. The high/low-context dimension (Hall, 1976) is based on preferences for high-context or low-context messages. High-context messages are covert with much non-verbal coding, while low context messages are overt and precise with verbalised details (De Mooij, 2009).

\section{Sample characteristics and data collection and analysis - Laddering interviews}

Reynolds and Olson (2001) suggest that the minimum sample size for laddering research is 20 respondents per subgroup. This is because a sample of 20 respondents can provide the required range of attributes, consequences and values. In addition, each participant provides around five ladders, each of which includes five elements on average. Thus ladders from 20 students would include a minimum of 500 data points (Reynolds \& Olson, 2001), which could provide considerable insight into student expectations during service recovery. Moreover, according to Ringberg, Odekerken-Schroder and Christensen (2007), collectively held cultural orientations can be identified from a relatively small sample. Therefore, in this study a total of 40 interviews have been held with British and Bangladeshi students in higher education. Convenience sampling has been chosen for selecting participants for this research, particularly because it allowed us to select Bangladeshi participants who are well-versed in the English language. This led to the minimisation of problems of translational equivalence and interpretation due to language differences that often threaten the validity of cross-national research (Mullen, 1995). More importantly, recent research on the concept of "national context effect" (Straus, 2009) states how samples that are not nationally representative can provide valid nation-to-nation differences: Straus' (2009) tests of validity conclude that nation-to-nation differences found on the basis of the student convenience samples are correlated with nation-to-nation differences found on the basis of other studies of the same or closely related variables. It is argued that, although using 
representative samples remains the preferred method whenever possible, if a study can only be done using convenience samples, this should not deter proceeding (Straus, 2009).

The students were aged between 21 and 29 years ( $X=23.5$ for the UK and $X=24.7$ for Bangladesh) both with genders being almost evenly represented. Both postgraduate and undergraduate students were included in the sample in an effort to achieve a range of student expectations and experiences across all levels of study at university. Moreover, by including participants studying in a wide range of areas in different education institutions, we attempted to counteract potential bias of reaching students in only one field of study. An added advantage of using student samples in cultural comparisons is that there is a reasonable degree of homogeneity among all participants, reducing the number of extraneous variables, which could contaminate comparative differences (Kanousi, 2005). All interviewees were asked which qualities professors should possess and which behaviours they should exhibit during faceto-face service recovery encounters. The attributes elicited through this paved the way for a series of 'Why is this important to you?' type of questions (Reynolds \& Gutman, 1988), which were intended to lead students up the ladder of related consequences and values. By probing every answer at the beginning ("how would you find out whether or not the professor is being friendly, competent, and so on"), and then asking interviewees to discuss the benefits of the mentioned attributes, we were able to distinguish between attributes/behaviours and consequences/benefits. The responses then acted as the starting point for the laddering probes to uncover a complete means-end structure. Questioning continued until respondents gave either circular answers, or were not able or willing to answer or had reached the value level.

Content analysis was conducted to code the raw data from the laddering interviews. The means-end chains of meaning for each participant were identified and the concept/phrases were classified as attributes, consequences and values, and codes were assigned. For example, the statement "solve the problem in a friendly way" was broken down into two meaningful chunks: "solve the problem" and "be 
friendly" and assigned two separate codes: "problem solution" and "friendliness". Both deductive and inductive coding was used. The use of deductive codes was aimed at enhancing coding reliability and keeping track of whether concepts being investigated are shared by other studies in the areas of service recovery (e.g. Tax et al., 1998), lecturer attributes (e.g. Voss \& Gruber, 2006) and human values (e.g. Rokeach, 1973).

With the help of the laddering software LADDERMAP (Gengler \& Reynolds, 1993), the review and alteration of coding was carried out where required. The codes for individual means-end chains were then aggregated and expressed in an implications matrix, which details the associations between the constructs. By showing the number of times one code leads to another (Reynolds \& Gutman, 1988), the implications matrix links the qualitative and quantitative elements of the technique. LADDERMAP generated two such implication matrices: one for each group of students. A section of the implication matrix for British students is illustrated in Table 1.

Table 1 Extract from Implication Matrix for British Students

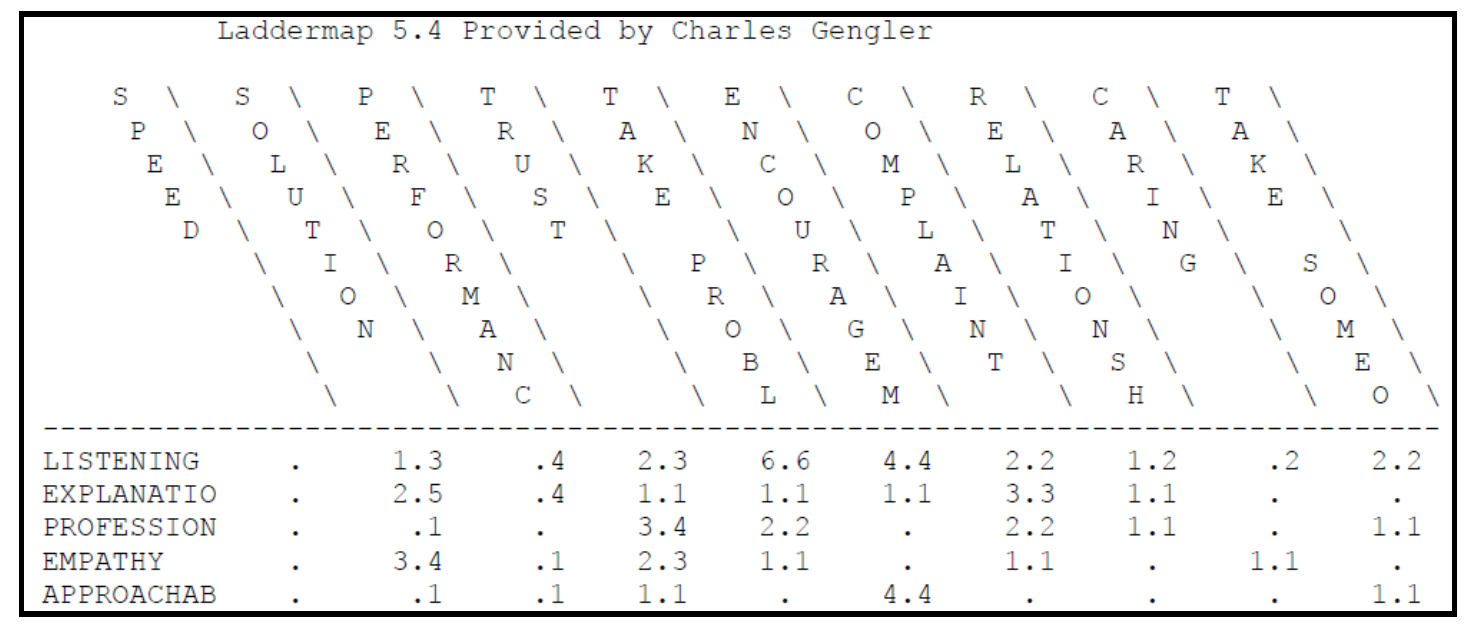

Table 1 reveals both direct and indirect relations or implications between concepts. The number of direct relations is presented to the left of the decimal and total implications (direct and indirect 
relations) are displayed to the right of the decimal. For example, "listening" leads to "take problem seriously" 6 times directly and zero times indirectly (6-6). Thus, 6 participants associated the professor's listening skills directly with taking the problem seriously and there were no indirect linkages between these two concepts. It is useful to examine both types of relationships in determining what paths are dominant in an aggregate map of relations among concepts (Reynolds \& Gutman, 1988). A higher number of direct relations indicate stronger relationships.

From the implication matrices, LADDERMAP automatically generated two hierarchical value maps (HVMs) that presented the aggregated chains graphically. While mapping the HVMs for British and Bangladeshi students, a cut-off level was determined to facilitate the reading of the map (Gruber, Szmigin \& Voss, 2006). For both maps, the cut-off level of three was chosen, which means that linkages had to be mentioned by at least three participants to be represented in the maps. This cut-off level was selected because it maintained the balance between data retention and data reduction and detail and interpretability (Gengler, Klenosky \& Mulvey, 1995).

Tables 2-4 display the 10 attributes (table 2), 13 consequences (table 3) and 6 values (table 4) which resulted from the content analysis of 40 interviews and which are displayed in the hierarchical value maps (HVMs) for both UK and Bangladesh. The tables indicate the number of times attributes, consequences and values were mentioned by the two groups of British and Bangladeshi students and the codes therein (in 'Name of Attribute' columns) are listed in alphabetical order. 
Table 2 Overview of all attributes

\begin{tabular}{|c|c|c|c|}
\hline $\begin{array}{l}\text { Name of } \\
\text { Attribute }\end{array}$ & $\begin{array}{l}\text { Number of } \\
\text { Times } \\
\text { Mentioned by } \\
\text { British Students } \\
\text { (in Ladders) } \\
\end{array}$ & $\begin{array}{l}\text { Number of Times } \\
\text { Mentioned by } \\
\text { Bangladeshi } \\
\text { Students } \\
\text { (in Ladders) } \\
\end{array}$ & $\begin{array}{c}\text { Characteristics } \\
\end{array}$ \\
\hline Active Listening & 27 & 26 & $\begin{array}{l}\text { Professors should listen to what their } \\
\text { students are saying with full attention, ask } \\
\text { questions and hear them out }\end{array}$ \\
\hline Approachability & 8 & 4 & $\begin{array}{l}\text { Students want professors to be easy to meet } \\
\text { and talk with. This means that the professor } \\
\text { should be available after class and during the } \\
\text { week }\end{array}$ \\
\hline Discussion & 0 & 7 & $\begin{array}{l}\text { Students want professors to discuss with } \\
\text { them possible ways to solve the problem, } \\
\text { asking about their preferences while taking } \\
\text { into account the opinions of their student } \\
\text { peers }\end{array}$ \\
\hline Empathy & 9 & 12 & $\begin{array}{l}\text { Professors should be willing to take the } \\
\text { student's perspective and be understanding } \\
\text { about the students' problems }\end{array}$ \\
\hline Explanation & 10 & 6 & $\begin{array}{l}\text { Professors should explain why the problem } \\
\text { has occurred and what action will be taken }\end{array}$ \\
\hline Friendliness & 5 & 12 & $\begin{array}{l}\text { Professors should give positive nonverbal } \\
\text { cues and behave in a friendly manner. } \\
\text { Friendliness is associated with nonverbal } \\
\text { signals like open body posture, casual } \\
\text { smiling, appropriate eye contact and a } \\
\text { positive tone of voice }\end{array}$ \\
\hline Take Time & 3 & 6 & $\begin{array}{l}\text { Professors should be patient and take } \\
\text { sufficient time to solve the problem }\end{array}$ \\
\hline $\begin{array}{l}\text { Open- } \\
\text { Mindedness }\end{array}$ & 1 & 21 & $\begin{array}{l}\text { Students want professors to be open to } \\
\text { criticism, new ideas and arguments. This } \\
\text { includes showing no sign of annoyance, bias } \\
\text { or defensiveness }\end{array}$ \\
\hline $\begin{array}{l}\text { Professional } \\
\text { Competence }\end{array}$ & 10 & 2 & $\begin{array}{l}\text { Professors should exhibit the ability to come } \\
\text { up with an intelligent solution based on their } \\
\text { professional knowledge, with complete focus } \\
\text { on the issue at hand }\end{array}$ \\
\hline Recording & 6 & 1 & $\begin{array}{l}\text { Students want professors to note down the } \\
\text { issue discussed and follow up on it }\end{array}$ \\
\hline
\end{tabular}


Table 3 Overview of all consequences

\begin{tabular}{|c|c|c|c|}
\hline Name of Consequence & $\begin{array}{c}\text { Number of } \\
\text { Times } \\
\text { Mentioned by } \\
\text { British } \\
\text { Students } \\
\text { (in Ladders) }\end{array}$ & $\begin{array}{l}\text { Number of } \\
\text { Times } \\
\text { Mentioned by } \\
\text { Bangladeshi } \\
\text { Students } \\
\text { (in Ladders) } \\
\end{array}$ & Characteristics \\
\hline Be at Ease & 6 & 9 & $\begin{array}{l}\text { Students want to be at ease while talking to the } \\
\text { professor }\end{array}$ \\
\hline Career Growth & 8 & 12 & $\begin{array}{l}\text { Students want to possess the skills and } \\
\text { qualifications that will aid career growth }\end{array}$ \\
\hline Complaint Handling & 13 & 12 & $\begin{array}{l}\text { Students want to believe that the professors } \\
\text { will handle the complaint }\end{array}$ \\
\hline Encouragement & 15 & 25 & $\begin{array}{l}\text { Students want to feel confident in articulating } \\
\text { their opinions and to feel that their opinions } \\
\text { are appreciated }\end{array}$ \\
\hline Knowledge & 4 & 28 & $\begin{array}{l}\text { Knowledge stands for the sum or range of } \\
\text { what has been perceived, discovered or } \\
\text { learned }\end{array}$ \\
\hline Learning Experience & 7 & 4 & $\begin{array}{l}\text { This refers to the extent to which students feel } \\
\text { they encountered a valuable teaching } \\
\text { experience at their institution }\end{array}$ \\
\hline Motivation & 7 & 15 & $\begin{array}{l}\text { This stands for the psychological feature that } \\
\text { arouses a person to take action toward a } \\
\text { desired goal and the reason for that action }\end{array}$ \\
\hline Performance & 23 & 10 & $\begin{array}{l}\text { Students want to successfully complete } \\
\text { assignments and pass exams }\end{array}$ \\
\hline Relationship & 12 & 8 & $\begin{array}{l}\text { This refers to a feeling of affinity and bonding } \\
\text { between the professor and the student }\end{array}$ \\
\hline Problem Solution & 43 & 55 & $\begin{array}{l}\text { Students want to get the impression that the } \\
\text { professors will solve the problem }\end{array}$ \\
\hline $\begin{array}{l}\text { Take Problem } \\
\text { Seriously }\end{array}$ & 17 & 2 & $\begin{array}{l}\text { Professors give the impression of taking the } \\
\text { problem seriously }\end{array}$ \\
\hline $\begin{array}{l}\text { Take Someone } \\
\text { Seriously }\end{array}$ & 9 & 7 & $\begin{array}{l}\text { Students want to get the impression that } \\
\text { professors take them seriously }\end{array}$ \\
\hline Trust & 20 & 16 & $\begin{array}{l}\text { This refers to a party's confidence that another } \\
\text { party, on whom the former must rely, will help } \\
\text { in reaching his/her goals }\end{array}$ \\
\hline
\end{tabular}


Table 4 Overview of all values

\begin{tabular}{|l|c|c|l|}
\hline Name of Value & $\begin{array}{c}\text { Number of Times } \\
\text { Mentioned by } \\
\text { British Students } \\
\text { (in Ladders) }\end{array}$ & $\begin{array}{c}\text { Number of Times } \\
\text { Mentioned by } \\
\text { Bangladeshi } \\
\text { Students } \\
\text { (in Ladders) }\end{array}$ & \multicolumn{1}{|c|}{ Characteristics } \\
\hline Harmony & 7 & 11 & $\begin{array}{l}\text { Students want to be free from } \\
\text { inner conflict }\end{array}$ \\
\hline Satisfaction & 9 & 4 & Students want to be satisfied \\
\hline Self-Actualisation & 6 & 2 & $\begin{array}{l}\text { Students want to achieve their } \\
\text { full potential }\end{array}$ \\
\hline Success & 5 & 5 & Students want to be successful \\
\hline Universalism & 4 & 3 & $\begin{array}{l}\text { Students want to take } \\
\text { responsibility for a better world }\end{array}$ \\
\hline Well-Being & 19 & 21 & Students want to feel happy \\
\hline
\end{tabular}

\section{Sample characteristics and data collection and analysis - Kano questionnaires}

The elicited attributes from the laddering interviews were then used to develop a Kano questionnaire, which also included attributes that respondents brought up during the laddering interviews but that were not mentioned frequently enough to be displayed in the HVMs such as e.g. "quick response" and "good communication skills" due to the chosen cut-off level. For each professorial attribute in the Kano questionnaire, respondents had to answer a question consisting of two parts: 'How do you feel if the feature is present?' and 'how do you feel if the feature is not present?' Respondents were, for example, asked "If a professor puts students at ease during the conversation, how do you feel?" (functional form of the question) and "If a professor does not put students at ease during the conversation, how do you feel?" (dysfunctional form of the question). For each question, respondents could then answer in five different ways: 1) I like it that way. 2) It must be that way. 3) I am neutral. 4) I can live with it that way. 5) I dislike it that way. Table 5 shows an example taken from the Kano questionnaire used in this study. 
Table 5 Example from Kano questionnaire

\begin{tabular}{|c|c|c|c|}
\hline \multirow[t]{5}{*}{ 6a. } & \multirow{5}{*}{$\begin{array}{l}\text { If a professor explains why the problem has } \\
\text { occurred and what action will be taken, how } \\
\text { do you feel? }\end{array}$} & 1. & I like it that way \\
\hline & & 2. & It must be that way \\
\hline & & 3. & I am neutral \\
\hline & & 4. & $\begin{array}{l}\text { I can live with it that } \\
\text { way }\end{array}$ \\
\hline & & 5. & I dislike it that way \\
\hline \multirow[t]{5}{*}{$6 \mathbf{b}}$. & \multirow{5}{*}{$\begin{array}{l}\text { If a professor does not explain why the } \\
\text { problem has occurred and what action will be } \\
\text { taken, how do you feel? }\end{array}$} & 1. & I like it that way \\
\hline & & 2. & It must be that way \\
\hline & & 3. & I am neutral \\
\hline & & 4. & $\begin{array}{l}\text { I can live with it that } \\
\text { way }\end{array}$ \\
\hline & & 5. & I dislike it that way \\
\hline
\end{tabular}

Kano questionnaires were handed out to 109 students in the UK and 101 in Bangladesh. There was a $100 \%$ response rate as the questionnaires were distributed in classrooms after lectures and returned immediately upon completion. Students were aged between 19 and 23 years $(X=20.8$ for the UK and $X=20.1$ for Bangladesh). $47 \%$ were male and $53 \%$ were female students at a university in the UK and $71 \%$ were male and $29 \%$ were female students at a university in Bangladesh. Using an evaluation table originally developed by Kano (1984), the attributes were then classified as recommended in Berger et al. (1993) and Matzler et al. (1996). The combination of the functional and dysfunctional forms of the question in the evaluation table led to different categories of requirements. For instance, if a student answered "I like it that way," to the functional form of a question - and answered "I am neutral," or "I can live with it that way," to the dysfunctional form of the question, then the combination of these questions in the evaluation table produced category A, indicating that the attribute is an attractive or excitement factor to the student. Beside the three categories relevant for our analysis (basic, performance and excitement factors), the evaluation table also allows the classification of requirements as indifferent, reverse or questionable (Matzler et al., 1996). Reverse features are those features that are not wanted by the student and they lead to actual dissatisfaction if present (Matzler et al., 1996). 
Questionable results identify a contradiction in the student's answer to the question and therefore act as a form of quality control for the Kano questionnaire (Matzler et al., 1996). However, there were no questionable results in the present study.

\section{Results and discussion}

\section{Service recovery expectations of British students (Laddering interviews)}

The HVM in Figure 1 presents 23 concepts of meaning among which six attributes, eleven consequences and six values can be identified. The size of the circles reflects the relative frequency with which participants mentioned a certain concept at this specific cut-off level. The thickness of the lines between concepts indicates the strength of the relationship. The attribute most desired by British students is "Active Listening", which was mentioned by 15 participants. This attribute leads to the highest number of consequences, that is, the immediate benefits students associate with the recovery attributes. The consequences of professors listening actively include making students feel at ease in the vicinity of the professor ("Be at Ease"), encouraging them to share their problems ("Encouragement"), creating the impression that the professor is taking their problem seriously ("Take Problem Seriously"), increasing their confidence in the professor ("Trust") and improving their perception about their learning experience at the university ("Learning Experience").

In particular, as the width of the linkage shows, British students strongly believe that listening attentively and responding appropriately means that the professor is taking their problem seriously ("Take Problem Seriously"), which they think will lead to a solution of their problem ("Problem Solution"), the consequence mentioned by $90 \%$ of the participants. Listening has been found to be an important service recovery strategy in previous studies as well (Duffy, Miller \& Bexley, 2006; Maxham, 2001). 
Figure 1 Hierarchical value map (UK)

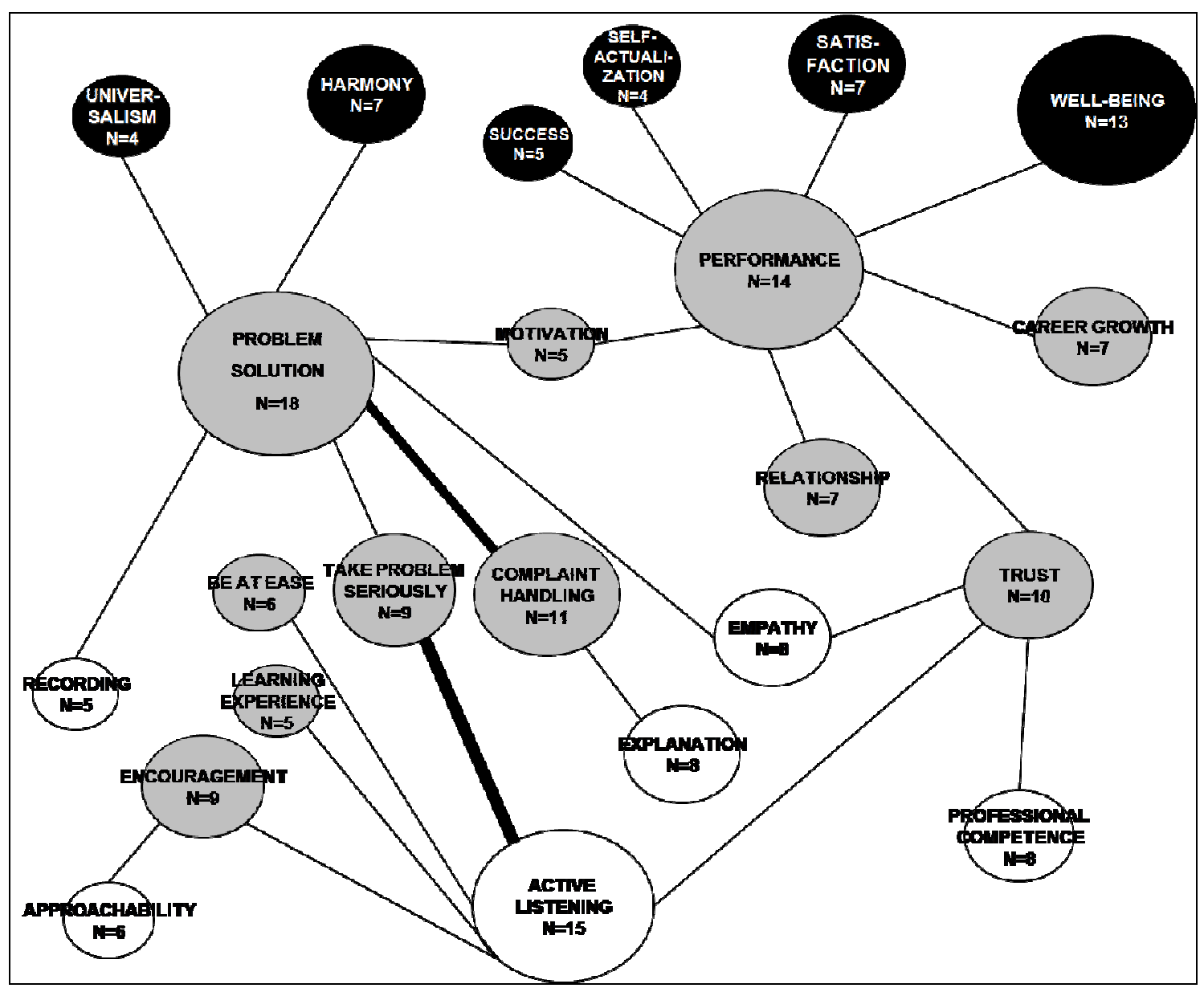

Note: Attributes=white, consequences $=$ grey and values=black; numbers $(N)$ refer to the frequency with which concepts were mentioned

The second most important attributes for British students are "Empathy" and "Explanation". This is in line with recent empirical work, which confirms that the use of explanations or causal accounts that include apologies and justifications, influence recovery satisfaction (Bradley \& Sparks, 2009; Mattila, 2006). Further, Swanson and Davis (2000) found that not explaining why the service failure occurred led students to recollect the encounter as dissatisfactory. Expressing empathy is also considered to be a fundamental part of the service recovery procedure (Seawright, Detienne, Bernhisel \& Larson, 2008) and has been found to influence interactional justice (Tax et al., 1998). McColl-Kennedy and Sparks' 
(2003) findings show that the service provider's lack of empathy can cause negative emotions in the customer, thus reducing satisfaction with service recovery. In the context of marketing education, Faranda and Clarke (2004) and Granitz, Koernig and Harich (2009) conclude that empathy is one of the factors that establishes rapport between the professor and students. In the HVM, empathy leads to the most important consequence "Problem Solution", as does "Explanation", but in this case the path is mediated by another key consequence, "Complaint Handling", which was mentioned by over half of the participants. Explaining why the problem has occurred and what can be done about it suggests to students that the professor is trying to handle the problem effectively and will solve it. Both "Complaint Handling" and "Take Problem Seriously" have been identified in the service recovery literature as important benefits customers desire during such encounters (Gruber, Szmigin \& Voss, 2006). When professors actively listen, empathise, provide an explanation and note down what has been discussed ("Recording"), students get the impression that their problem will be solved. Recording thus appears to provide a tangible cue to students of effective service recovery. To our best knowledge, the attribute "Recording" has so far not been proposed as a desired attribute of contact employees during service recovery from the customer's point of view. However, the attribute has been recommended as part of good practice complaint management (Nyer, 2000) and Harris and Ogbonna (2010) argue that failing to record the complaint often means that the complaint will not be dealt with.

Actively listening and empathising with British students leads to trust in the professor and trust is further instilled in students by exhibiting professional competence in the encounter. "Professional Competence" consists of four core components: cognitive competence, functional competence, behavioural competence and ethical competence, all of which contribute to the employee's effective performance (Cheetham \& Chivers, 1998). Gruber et al. (2006) found competence to be the most desired attribute of customer contact employees within complaint handling encounters. These findings are also aligned with sales management research where "Competence", as a function of salesperson 
behaviour, has been found to be a determinant of customer trust (Kennedy, Ferrell \& Leclair, 2001; Swan, Bowers \& Richardson, 1999). British students believe that when trust exists between them and the professor, it translates into better academic performance ("Performance"), which in turn leads to a better start for their careers. The relationship between student trust and performance has been empirically validated in an education background by Lee (2007) who found a positive relationship between student trust in teachers and achievement in school.

"Performance" is the second most important consequence for British students, reinforcing four values, which stand for the ultimate reasons why students desire such concepts during service recovery encounters. When students perform well academically, they believe that they are realising their full potential ("Self-Actualisation") and it gives them a sense of achievement ("Success"). In addition, good performance also leads to feelings of happiness ("Well-Being") and sense of "Satisfaction". Apart from these four, two other values are held important by British students: "Harmony" and "Universalism", both being reinforced by having a solution to the problem ("Problem Solution"). Students feel free from inner conflicts ("Harmony") when problems are resolved. At the same time, they fulfil the need to help improve the services provided by their institution, from which their peers and future students can benefit ("Universalism").

\section{Service recovery expectations of Bangladeshi students (Laddering interviews)}

The HVM for Bangladeshi students (Figure 2) portrays 23 concepts of meaning, of which seven concepts can be identified as attributes, twelve concepts as consequences and four concepts can be interpreted as values. 
Figure 2 Hierarchical value map (Bangladesh)

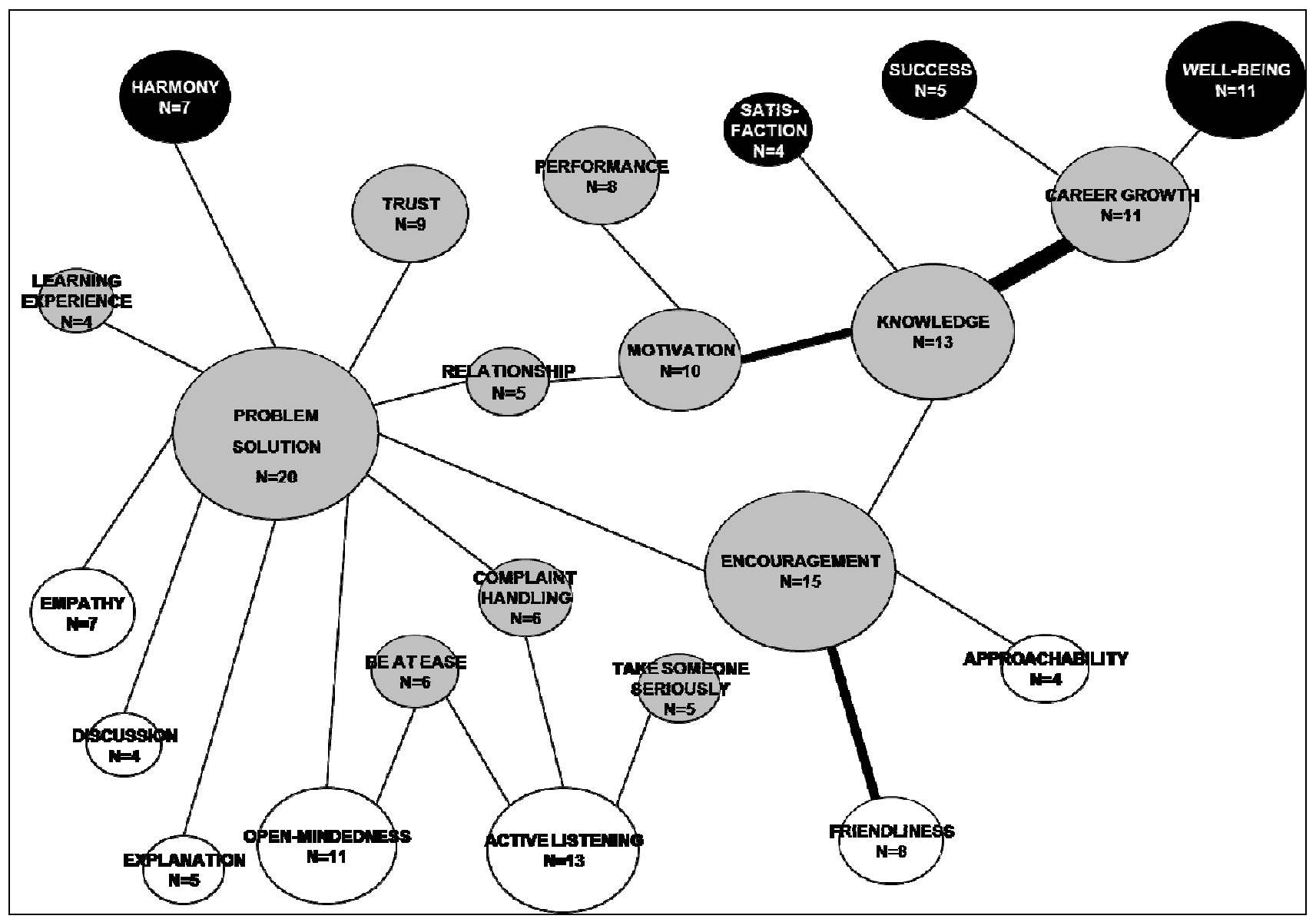

Note: Attributes=white, consequences=grey and values=black; numbers $(N)$ refer to the frequency with which concepts were mentioned

The HVM shows that Bangladeshi students consider "Active Listening" to be the most important attribute (mentioned 13 times). The importance placed on this concept echoes again what is suggested by the service recovery literature (Zemke $\&$ Bell, 2000). When the professor portrays this attribute during recovery encounters, it makes students feel comfortable around the professor ("Be at Ease") and shows students that they are taking them seriously ("Take Someone Seriously"). The attribute "Active Listening" also shows students that the professor will handle the complaint in a way that will lead to a problem solution. However, compared to findings from previous research on complaint handling encounters in a European context (Gruber et al., 2006), the consequences of "Complaint Handling" and 
"Take Someone Seriously" do not emerge as dominant consequences for Bangladeshi students. Students are also made to feel at ease and believe that the professor will solve the problem when they perceive the professor accepts criticism positively, meaning he/she shows no sign of bias or annoyance (“Open-Mindedness”). This attribute seems to be quite important to Bangladeshi students because it was mentioned by over half the participants. Students perceive that professors will solve the problem when they are empathetic, react well to criticism (“Open-Mindedness"), provide an explanation and ask for student input regarding the preferred solution by engaging in a discussion. This also indicates that Bangladeshi students want professors to come up with a solution by soliciting and discussing their opinions and those of their peer group. The focus on the concept of solicitation and discussion echoes the importance of a concept introduced by Karande, Magnini and Tam (2007) called "recovery voice", which entails a service provider asking a customer (after a failure has occurred) how the problem can best be rectified and which has been found to result in higher post-failure satisfaction.

Although "Active Listening" and "Open-Mindedness" are the most frequently mentioned attributes, the strongest path (resulting from highest number of direct relations between concepts) links the attribute "Friendliness" to "Encouragement", this consequence being mentioned by 15 participants. Research on service recovery in the hospitality industry also found that employees who display positive nonverbal behaviours, that is, friendliness, are seen by customers to be highly credible, competent, courteous and trustworthy (Yuksel, 2008). Gruber et al. (2006) also found perceived friendliness to be the second-most desired attribute of customer contact employees during complaint handling encounters. Friendliness has further been established as a critical quality dimension of professors in general (Voss, 2009).

Bangladeshi students believe that when professors are approachable and friendly, they are encouraging them to share their problems and appreciating their opinions. "Encouragement" is the second-most important consequence and is placed in a triad connecting it to "Problem Solution" and 
"Knowledge". This triad embodies the most important consequences of desired professorial behaviour during service recovery. Bangladeshi students perceive that when they can share their problems and opinions confidently and this is appreciated by the professor, it leads to a greater chance of recovering from the problem ("Problem Solution") and they are able to learn more ("Knowledge") from the professor. The consequence "Problem Solution" has also been linked to developing trust in the professor. This is supported by findings that show that remedying a service failure helps reinstall customer trust in the service provider (Kau \& Loh, 2006; Tax et al., 1998). Students also believe that a problem solution helps them in knowledge acquisition by enhancing the relationship between teachers and students, which provides motivation for students to perform better and especially to learn more, as shown by the strong linkage between "Motivation" and "Knowledge". This is supported by education research, which concludes that students' motivation can be influenced by their attitudes towards the instructor (Zhang \& Oetzel, 2006). In addition, it is also consistent with findings that rapport between students and faculty can increase students' motivation to learn as well as their willingness and confidence to use the faculty as a resource for learning (Granitz et al., 2009; Faranda \& Clarke, 2004). Bangladeshi students also believe that a problem solution leads to a favourable perception about their learning experience at their institution, which backs Bhandari, Tsarenko and Polonsky's (2007) argument that an evaluation of service recovery performance leads to an overall evaluation of the service experience.

Bangladeshi students associate knowledge acquisition even more strongly with "Career Growth", indicating that they believe that the more they learn, the more they will be able to excel in their professions. A thriving career reinforces the values "Well-Being" and "Success" in Bangladeshi students, while acquisition of knowledge gives them a sense of "Satisfaction". When professors solve their academic problems, it contributes towards a feeling of "harmony" within them. 


\section{Comparison of service recovery expectations of British and Bangladeshi students}

While many of the same attributes, consequences and values appear in the two HVMs, there are a few concepts which appear in only one of the HVMs. In terms of similarities, the two HMVs reveal that British and Bangladeshi students identify "Active Listening" as the chief attribute they desire in professors during service recovery encounters. Both Bangladeshi and British students mentioned that, among other consequences, they feel at ease during conversations with professors as a result of this attribute. Other attributes displayed by the HVMs that are common to both groups include "Empathy", "Explanation" and "Approachability". Approachability is a noteworthy attribute because it holds importance for both British and Bangladeshi students and being accessible and available to students regularly has also been identified as a desired teaching quality of professors in a study using the meansend framework (Voss \& Gruber, 2006). It also indicates that the actions and attitudes of service personnel play a critical role in encouraging customer organizational citizenship behaviours, such as voice ( Bove, Pervan, Beatty \& Shiu, 2009). Regarding students' expectations about the attributes of professors, it appears that certain attributes such as empathy, approachability and friendliness are expected in professors in general (Faranda \& Clarke, 2004) and during recovery encounters as well.

The results obtained from this study corroborate previous research findings that listening actively, showing empathy and providing explanation are key attributes that customers desire in contact employees during service recovery encounters (Gruber et al., 2006). The findings also confirm that although similar attributes of service providers may be desired during service recovery encounters across cultures, the relative importance attached to each attribute differs (Kanousi, 2005). In particular, the HVM for Bangladeshi students displays the attributes "Open-Mindedness", "Discussion" and "Friendliness", none of which are displayed by the British students' HVM.

On the other hand, the HVM for British students displays the attributes "Professional Competence" and "Recording", which do not appear in the Bangladeshi student HVM. British students consider 
"Empathy", "Explanation" and "Professional Competence" to be the most important after "Active Listening”. By contrast, for Bangladeshi students, "Open-Mindedness", "Friendliness" and "Empathy" are the most important attributes after "Active Listening".

The relatively greater emphasis placed on the friendliness attribute by Bangladeshi students is suggestive of the importance of nonverbal communication which is typical in high-context, collectivistic cultures (Hall, 1976; Hofstede \& Hofstede, 2005). In high-context cultures, nonverbal communication is important in the interpretation of a message. Collectivists depend more on nonverbal cues in face-to-face interactions to convey, as well as to discern, desires, concerns and preferences (Chen, Chen \& Meindl, 1998). In line with this, Bangladeshis show a higher reliance on "Friendliness" and derive from these positive nonverbal cues that the professor is appreciative of their opinions and will engage in effective service recovery. On the contrary, in low-context cultures, explicit verbal communication takes place, that is the message itself is given more importance than nonverbal cues (De Mooij, 2009). Hence it can be seen that after “Active Listening”, British students place greater importance on attributes involving more explicit verbal messages such as "Explanation", "Empathy" and "Professional Competence", instead of "Friendliness".

Further, British students place a higher emphasis on "Recording", which can be regarded as a desired tangible cue to indicate that their problem will be solved. This is backed by research in the hospitality industry which concludes that people from European (individualistic) cultures are more likely than their Asian counterparts (collectivistic) to rely on tangible cues in the service evaluation process (Mattila, 1999).

In high power distance countries such as Bangladesh, the educational process is argued to be more teacher-centred; teachers in Bangladesh outline the intellectual paths to be followed to a higher degree when compared to low power distance countries (Hofstede \& Hofstede, 2005). Additionally, in collectivistic cultures, direct confrontation with another person is considered rude and undesirable and 
the need for maintaining harmony is high. The combined influence of these two cultural dimensions is reflected in the findings where Bangladeshi students consider "Open-Mindedness" to be the second most important attribute, that is they desire the professor to accept criticism, new ideas and arguments and to maintain harmony. The important role "Friendliness" plays in providing "Encouragement" also reflects the fact that Bangladeshi students need to be appreciated and given a boost of confidence when they attempt to face a professor who in their high power distance culture, is never publicly contradicted or criticised and treated with deference (Hofstede \& Hofstede, 2005). This is an important finding because it emphasizes further that professors play a critical role in encouraging voice behaviour among Bangladeshi students, who are unlikely to speak up without such encouragement. An equally high need for "Open-Mindedness" in the professor, "Friendliness" and its consequence "Encouragement" has not been observed in British students. This is because in low power distance individualistic countries like the UK, speaking one's mind is normal and "a clash of opinions is believed to lead to a higher truth" (Hofstede \& Hofstede, 2005: p. 87). Although mentioned only four times, the fact that Bangladeshi students desired the attribute of "Discussion" and their British counterparts did not is also indicative of a cultural discrepancy. Collectivists emphasise group membership and they value collective needs and goals while individualists value individual needs and believe that every individual is unique (Hall, 1976; Hofstede \& Hofstede, 2005). This means that in expecting the professor to solicit their and their peer group's opinion, Bangladeshi students are emphasising group membership and affiliative benefits.

Among all the consequences mentioned, the importance of "Problem Solution" is paramount to both groups, which is consistent with previous research on service recovery encounters (Gruber et al., 2006). Moreover, the dominant status of this consequence is exemplary of the findings within Iyer and Muncy's (2008, p. 30) on service recovery, where they concluded that "the big issue in the student's mind appears to be whether or not the faculty member effectively dealt with the service failure". However, differences in the importance of other consequences can be observed. For example, in the 
HVM for Bangladeshi students, a solution to the problem leads to better professor-student relationships, which fosters motivation to learn more from the professor and also to perform better. However, the HVM for British students indicates that it is the solution to the problem, meaning the outcome of service recovery, that is important in motivating students to perform better. Two issues are noteworthy here. First, Bangladeshi students explicitly link "Relationship" to important consequences more so than their British counterparts. This is again suggestive of the greater influence of interpersonal relationships in collectivistic cultures. For Bangladeshi students, social relationships play a larger role in regulating behaviour and in the classroom, the teacher-student relationship is important because students look up to the professor not only as a teacher but as a model of correct behaviour (Hofstede \& Hofstede, 2005). Second, "Performance" plays a prominent role for British students whereas Bangladeshi students emphasise knowledge acquisition more than performance. The high agreement across values shows that students hold similar values in higher education settings. Both groups value "Satisfaction", "Success", "Harmony" and above all, "Well-Being". The importance of these values is consistent with findings from higher education literature on student expectations (Voss, Gruber \& Szmigin, 2007) and also with findings from studies in complaint-handling encounters involving student samples (Gruber et al., 2006). However, compared to former studies, the value of "Harmony" emerged as a more important concept in this study. Both British and Bangladeshi students frequently related "Problem Solution" to the attainment of "Harmony". This can be attributed to the context of the study, which involves recovery from service failures and also to the nature of higher educational services. Patterson, Romm and Hill (1998) view higher education as a continuous service since a typical student takes a number of years to consume the service, drawing an analogy to a highinvolvement, durable product purchase. It can thus be argued that effects of service failures in higher education may be experienced for a prolonged period. Therefore, "Harmony" emerges as an important desired end-state for students. The absence of values such as "Universalism" and "Self-Actualisation" 
in the HVM for Bangladeshi students suggests that lower importance is attached to these values. "SelfActualisation" can be immediately related to individualistic cultures, perhaps because individualists strive for self-actualisation and collectivists strive for actualisation not of the self but the self as part of the group (De Mooij, 2009). However, one would intuitively expect that "Universalism" would feature more prominently in the HVM for the collectivistic Bangladeshis than the HVM for individualistic British. Regarding this value of "Universalism" often expressed in statements like "help the world become a better place", Ahuvia (2002: p.29) argues that collectivism is not based on this kind of universalistic altruism so much as fulfilling one's social roles and meeting one's responsibilities to the in-group. Thus, collectivists may be higher in loyalty to the in-group, but they may be no higher in universalistic feelings than individualists (Ahuvia, 2002). In the following sections, the relative impact of the service recovery attributes mentioned by students is evaluated using Kano methodology.

\section{Impact of professor attributes on students'(dis)satisfaction with service recovery (UK)}

The following matrix charts (Figures $3 \& 4$ ) illustrate which attributes are basic, performance and excitement factors for students in the two countries. The Kano map in Figure 3 illustrates which attributes of professors are "basic factors" that students in the UK take for granted, "performance factors" for which the relationship between attribute performance and (dis)satisfaction is linear and excitement factors that delight UK students during service recovery encounters. The map in Figure 3 reveals that all attributes of professors are performance factors. Thus, British students do not take any of the professorial attributes for granted in the case of service recovery encounters. There are also no attributes that have the potential to delight students. "Friendliness" is the only attribute that is close to the area of excitement factors, stressing again the importance of this attribute for students. 
Figure 3 Kano map (UK)

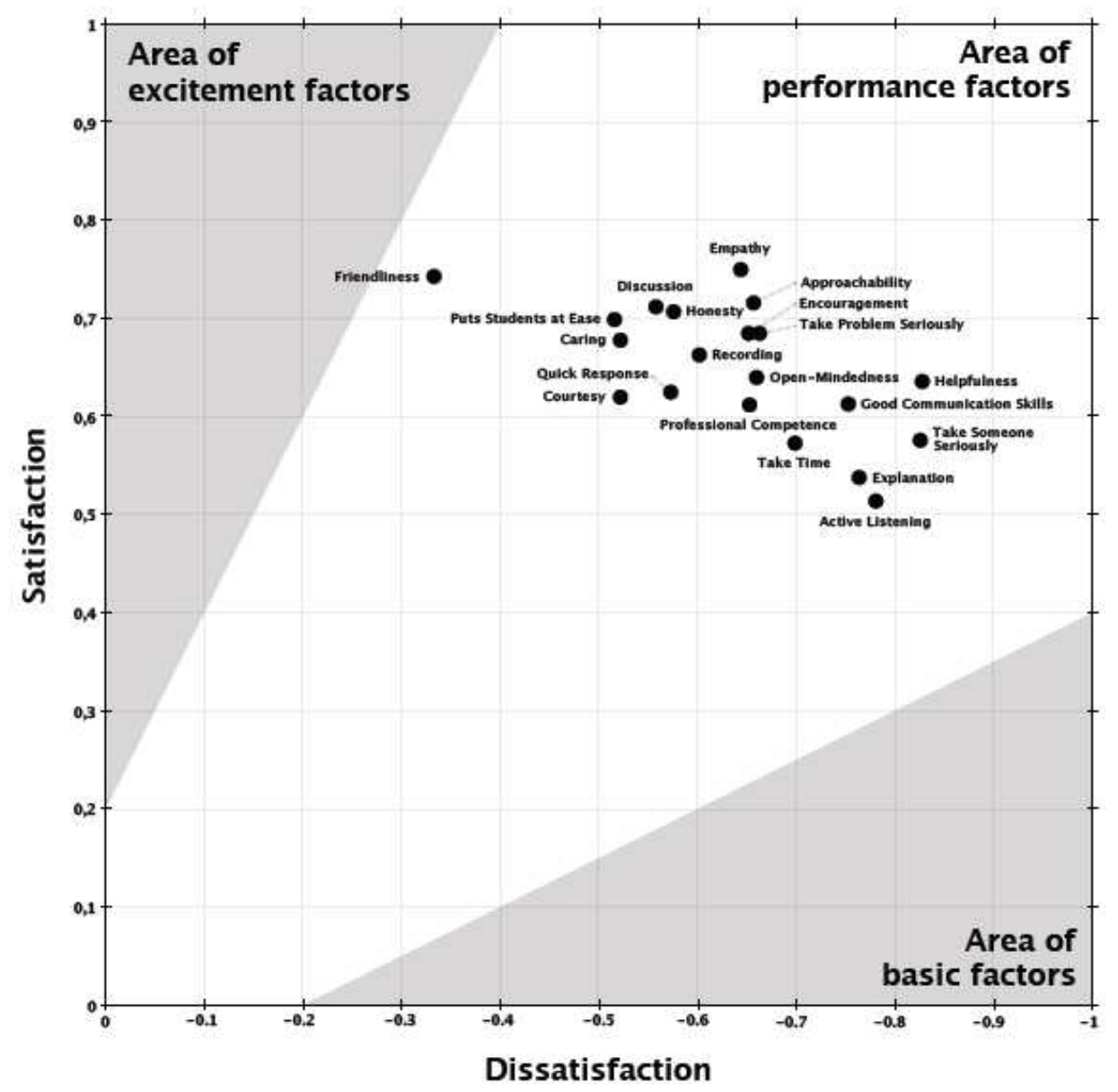

"Empathy" has the strongest impact on satisfaction for British students, which supports the laddering result that indicated that this attribute was the second most important attributes for students. The map also reveals that if professors are perceived not to be helpful ("Helpfulness") and do not show respect to students ("Take Someone Seriously"), then students will be very dissatisfied.

\section{Impact of professor attributes on students'(dis)satisfaction with service recovery (Bangladesh)}

Figure 4 shows that for Bangladeshi students, the majority of attributes are performance factors, with "Encouragement" having the strongest impact on satisfaction followed by "Approachability", stressing again the aforementioned importance of these two attributes for students in this country. 
Figure 4 Kano map (Bangladesh)

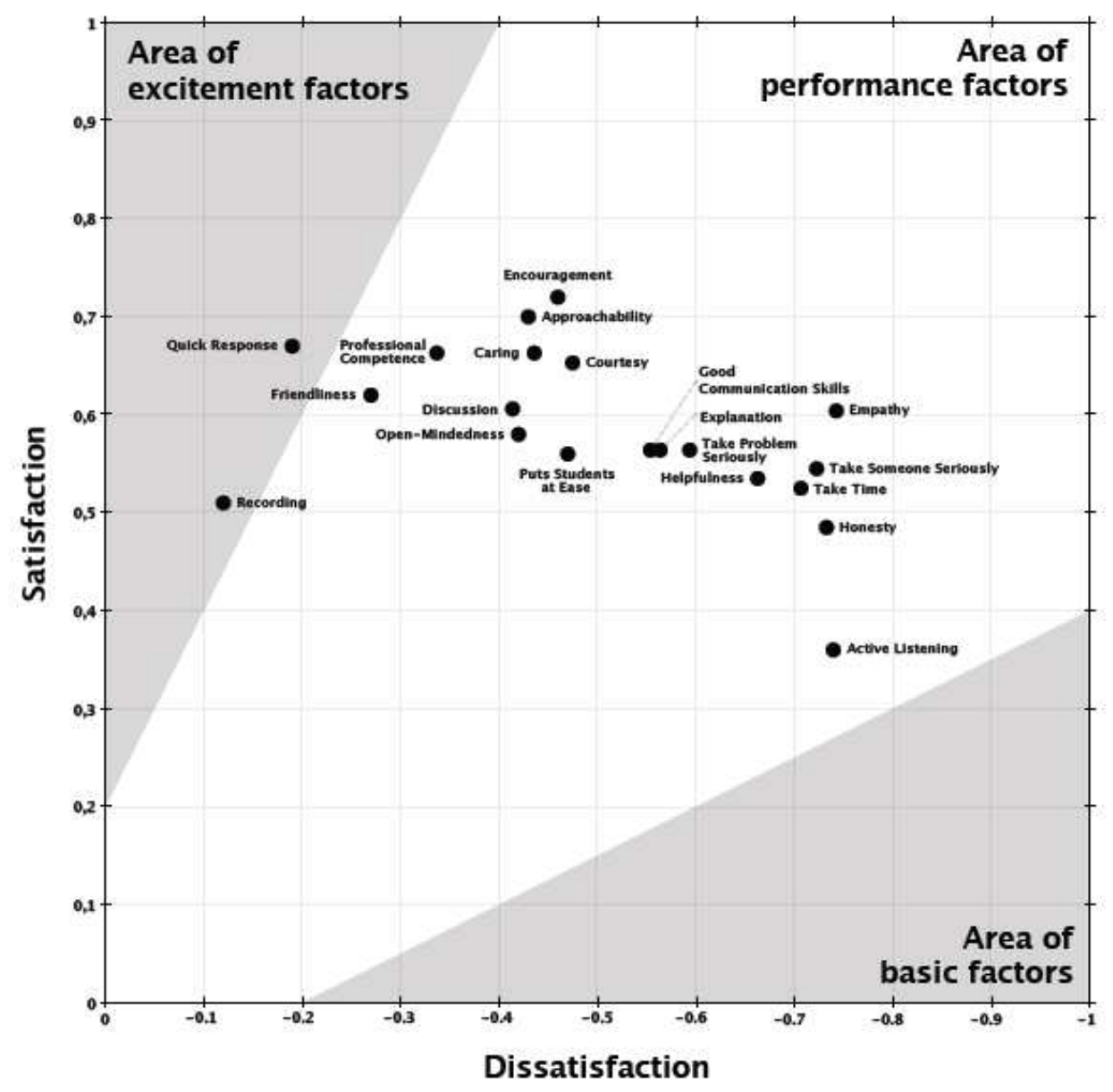

Two attributes are excitement factors ("Quick Response" and "Recording") that have the potential to satisfy Bangladeshi students very much but that do not increase dissatisfaction if professors do not possess them. Respondents brought both attributes up during the laddering interviews but they did not mention these concepts often enough for them to be displayed in the HVM. Thus, students in Bangladesh do not expect their professors to respond quickly and take notes during the service recovery encounter but they would be very satisfied if they would do so. "Friendliness" and "Professional Competence" are also close to the area of excitement factors. The Kano map also reveals that students are very dissatisfied if professors do not understand their perspective ("Empathy"), do not show respect ("Take Someone Seriously") and if they do not appear to be sincere and do not ensure 
transparency ("Honesty"). The finding that the attribute "Take Someone Seriously" has the potential to dissatisfy students strongly if professors do not show respect to students corroborates with previous research by authors such as Voss et al. (2007), who showed that students wanted to be taken seriously and treated with respect. The Kano map also shows that Bangladeshi students are most dissatisfied if professors do not listen to them ("Active Listening"). It appears that students take the professors ability to listen carefully to what they have to say during the service recovery encounter almost for granted (the attribute is close to the area of basic factors), indicating that its absence will have serious results for higher education institutions. This corroborates previous research by Gruber, Reppel, Szmigin \& Voss (2008) who showed that complaining customers take the frontline employee's ability to listen actively to them for granted. Professors have to realise that they cannot impress their complaining students just by listening to them actively, as they already expect this behaviour. Nevertheless, it is a very important attribute to get right in order to prevent dissatisfaction.

\section{Implications for higher education institutions}

The analysis of student expectations across two cultural groups shows that, for professors to deal with service failures effectively they should be approachable to students, show empathy, provide an explanation for the failure and above all, they should listen actively. The quality of listening may easily be taken for granted, however effective listening goes beyond merely hearing the student out to actually getting the meaning of what is being said (Mount \& Mattila, 2002). Anderson and Martin (1995) point out that listening behaviour involves three components: attentiveness, perceptiveness and responsiveness. In addition, understanding what lies behind student expectations is important for professors because it would prevent them from becoming defensive in such situations and make them conscious of their potentially negative behaviours (Swanson \& Davis, 2000). This knowledge would also allow professors to avoid misunderstandings that may affect the teacher-student relationship and prepare professors to take a stance towards proactive service recovery. 
For professors who teach abroad and who teach classes attended by international students, this study holds the important implication that in case of service recovery encounters, students from different national cultures expect them to behave and react in different ways. By identifying how British and Bangladeshi students show a preference for task and relationship attributes of service recovery respectively, the research highlights the importance of taking into account national cultural differences to ensure student satisfaction with service recovery. However, professors should be careful about the use of cultural stereotypes in the classroom (Littlewood, 2001). For example, national cultural differences do not mean that in any given situation one may not find an individual Western student showing evidence of an interdependent orientation and an individual Asian student affirming his/her independent self (Littlewood, 1999). Independent self and interdependent self are the personbased concepts of individualism and collectivism respectively proposed in psychological research (Markus \& Kitayama, 1991). Although individual level variations exist, a large number of studies confirm that when responses of Asians (collectivists) and Westerners (individualists) are examined over a given range of situations, Asians have a greater tendency to perceive themselves as interdependent selves (Littlewood, 1999; Markus \& Kitayama, 1991). This finding, in addition to the evidence that individual level variables such as attitude and values are influenced by national culture (Steenkamp, Hofstede \& Wedel, 1999), indicates that national culture matters even at the individual level. Ultimately, one of the outcomes of this research is to bring about an appreciation in professors and higher education institutions regarding the role of culture in the delivery of quality service. The research findings suggest that professors' actions during service recovery need to be customised to better meet the expectations of students belonging to different national cultures.

Higher education institutions also have a major role to play in terms of ensuring effective service recovery performance. In terms of internal marketing, institution management should provide appropriate interpersonal and intercultural communication skills training to professors, especially to 
those who are new to the teaching profession (Frankel et al., 2006) and those who teach in foreign branches of the institution. Students also hold the view that having a mentor who is culturally responsive and aware is important for having a successful mentoring relationship (Chung, Bemak \& Talleyrand, 2007), which is defined as a process of teaching, protecting, guiding, nurturing, supervising and advising someone with the intent to facilitate professional and personal growth (Schwiebert, 2000). Therefore, professors who possess intercultural communication competence (Wiseman, 2002) are likely to be able have more fruitful mentoring relationships with students.

The study also holds implications for external marketing by educational institutions. The introduction of student satisfaction guarantees (McCollough \& Gremler, 1999) would enhance student confidence in professors and establish accountability on both sides (Gremler \& McCollough, 2002). Service guarantees have also been found to influence the outcome of service recovery as they affect how employees behave to recover the customer (Lidén \& Skålén, 2003). In addition, service guarantees increase the likelihood of students voicing their problems (Bove \& Robertson, 2005), which can lead to further service process improvements (Johnston \& Michel, 2008). Moreover, keeping in view that the branding of universities has become a source of competitive advantage in the higher education market (Hemsley-Brown \& Goonawardana, 2007; Wæraas \& Solbakk, 2009; Chapleo, 2010), the results of this study provides ideas for the development of the brand image of an educational institution by shedding light on the benefits and values that are important to students. Traditionally, the means-end framework has been used to design positioning strategies for products and services (Reynolds \& Gutman, 1988). Based on the findings, it is evident that students across cultures are significantly concerned with their career prospects and associate many benefits such as knowledge acquisition, performance and student motivation to the effective service performance of professors. Bennett and Ali-Choudhury (2009) found that students' perceptions of the most critical dimensions of a university brand consists of students' prospects on graduation and the institution's learning environment, 
especially arrangements for student support. University professors also play a role in the formation of the university's brand reputation according to Priporas \& Kamenidou's (2011) study. Hence, educational institutions, when defining their brand identity, should focus on aligning it with the benefits and the ultimate values sought by students (Hemsley-Brown \& Goonawardana, 2007; Heslop \& Nadeau, 2010). This also includes highlighting the quality and expertise of its teaching staff in all marketing communication including websites and brochures (Bennett \& Ali-Choudhury, 2009) and implementing marketing strategies that allow for a greater role of faculty, for example, during open days. By establishing the need for effective service recovery practices, the study does not suggest that professors "pander to students" (Swanson \& Davis, 2000, p. 23) or that students are always right (Scott, 1999). However, it is reasonable to suggest that a learner-centred orientation (Cornelius-White, 2007) is at least required to ensure that any service failures, whether real or perceived, do not detract from the student's learning experience.

\section{Limitations and directions for further research}

To our best knowledge, this study is the first that uses laddering interviews and Kano questionnaires to investigate service recovery in higher education in two different countries. The results present a rich insight into the service recovery expectations of students in higher education and provide a starting point for further research. However, as with any exploratory research, the findings of this study are tentative in nature. The use of convenience samples of students limits the generalisability of the findings, however this is offset to an extent by drawing participants from various institutions studying in a wide range of areas including business, law, engineering and medicine. Furthermore, as Greenberg (1987) points out, the potential for generalisability is not always something that can be achieved in any one study, but it is often an empirical question that requires comparisons over different studies. Thus, what is now needed is similar research with different sample populations. Results from these studies could then be compared and differences and similarities revealed. Even though our study has sample 
sizes similar to several existing laddering (Reynolds \& Olson, 2001) and Kano studies (Löfgren \& Witell, 2008), future research studies could still use larger probability samples that represent the broader (complaining) student population in the selected countries.

This study provides evidence in support of cultural differences in student expectations of professors' attributes during service recovery. Future studies should also explore the influence of failure type and gender, given that both the type of failure (Smith, Bolton, \& Wagner, 1999) and gender (McColl-Kennedy, Daus \& Sparks, 2003) have been found to be moderating variables during service recovery in other industries. In addition, whether students' characteristics such as their year at university and the specific area of study affect these results are worthy of research. Moreover, not all recovery situations in higher education will involve face-to-face interactions, especially considering the growth of distance learning courses (Swanson et al., 2005). Thus recovery encounters via email and telephone should also be investigated.

Further, fellow researchers could conduct studies at different points in time to investigate the movement of quality attributes of professors in both countries over time. Authors such as Johnson, Herrmann and Huber (2006) and Thompson, Hamilton and Rust (2005) have recently shown that customers experience quality attributes differently over time. Similarly, Kano $(2001 ; 2006)$ showed that attributes are dynamic and not static. In particular, he found that for some products such as the television remote control, product attributes have a life cycle with excitement factors deteriorating to performance factors and then basic factors over time. In a service context a similar life cycle exists: Attributes of newly-introduced services can delight customers at the beginning of the life cycle but become expected over time. For example, Nilsson-Witell and Fundin (2005) found that after using an e-service (online ordering of cinema tickets) five or more times customers perceived the service as a performance or even basic factor. According to Löfgren and Witell (2008, p. 72), the life cycle of quality attributes concept "is one of the most interesting and fruitful developments of the theory of 
attractive quality". Future research could investigate whether the life cycle phenomenon that NilssonWitell and Fundin (2005) discovered in a service context also holds true for attributes of professors in service recovery encounters. It could therefore be expected that the current excitement factors for Bangladeshi students will deteriorate to performance factors and maybe later even to basic factors. Similarly, several performance factors could deteriorate to basic factors for British students. However, future research could also reveal that some quality attributes remain static for a prolonged period of time (Kano, 2001). Research in the UK could also focus on identifying attributes of professors that can create not only service recovery satisfaction but even service recovery delight (excitement factors).

Finally, it should also be noted that Hofstede's dimensions of national culture were developed based on work-related values (Hofstede, 2001). Hofstede (2001) linked these dimensions with demographic, geographic, economic and political aspects of a society, a feature that is unmatched by other frameworks (Soares, Farhangmehr \& Shoham 2007). Although Hofstede's dimensions are the most widely used ones in psychology, sociology and marketing studies (Steenkamp, 2001), it is argued that other frameworks such as Schwartz's (1994) framework for national cultural values include elements of culture that may not be captured by Hofstede's model ( $\mathrm{Ng}$, Lee \& Soutar, 2007). Ng et al. (2007) suggest that since Schwartz (1994) utilised teachers and students in his sample, his framework may be more appropriate for use in non-work related contexts ( $\mathrm{Ng}$ et al., 2007). It thus remains to be explored whether frameworks other than Hofstede's (2001) yield a greater depth of insight into the influence of national culture on service recovery expectations.

\section{Concluding statement}

Overall, our findings corroborate previous research which conclude that national culture plays a significant role in shaping expectations during service recovery encounters (Kanousi, 2005; Mattila \& Patterson, 2004b). In particular, they mirror results from service recovery research where customers from individualistic cultures have been found to emphasise the service's functional or transactional 
elements but customers from collectivistic cultures have been found to emphasise the more intangible relational dimensions of the service (Winsted, 1997). The findings indicate that British students seem to be concerned with attributes and consequences related more to the task of service recovery, while Bangladeshis seem to prioritise attributes and consequences related to the interaction between the professor and the student. This task versus relationship emphasis of individualists and collectivists is also in line with cross-cultural marketing and communication studies (De Mooij, 2009).

The major contributions of this research lie in connection with service recovery research in higher education and cross-cultural services marketing, areas in which limited knowledge is available. The study provides a first insight into the expectations of students concerning professors' attributes during service recovery and identifies the existence of preferences among students for certain attributes and benefits based on national cultural differences. The findings thus provide strong directions for practice on the part of professors. The findings contribute to service recovery research further by showing the links between specific service recovery behaviours to both positive student outcomes and service performance, identifying which attributes have the strongest impact across cultures at the same time. Although earlier service recovery research in other service industries has arrived at similar findings, few have attempted to examine what lies behind the attributes of "Empathy", "Explanation" and "Friendliness" that customers ask for and the values customers want to reinforce through the service experience. Previous studies have also failed to consider which attributes add value (e.g. "Recording") and which attributes only meet minimum requirements, as indicated by the Kano method in the present study.

Therefore, a strong contribution of this paper is the finding that the concepts gleaned from the laddering interviews that are shown in the hierarchical value maps must not been seen in strict isolation, as in previous research, but have to be understood as a network of interrelated concepts. In other words, professors can improve their service recovery activities by not just portraying the 
attributes desired by students, but by assessing these in a way that their impact is linked to the perception of the students regarding the important consequences (e.g. the feeling of being taken seriously) and personal values or motivations (e.g. being at harmony). By combining the laddering and Kano methods, researchers can reveal how these commonly unidentified elements are interconnected and interdependent and also evaluate the relative impact of each element on student (dis)satisfaction. This can then help professors realise that focusing on concepts in isolation (e.g. professors being competent or friendly) is not sufficient for recovering dissatisfied students in face-to-face service recovery encounters. It also equips them with the knowledge of behaviours that can create student satisfaction and behaviours which they should exhibit to avoid student dissatisfaction during such recovery encounters. In the context of higher education, professors can leverage all this information to enhance the professor-student relationship and to foster positive student outcomes. 


\section{References}

Abdullah, F. (2006). Measuring service quality in higher education: Hedperf versus servperf. Marketing Intelligence and Planning, 24(1), 31-47.

Ahuvia, A. (2002). Individualism/collectivism and cultures of happiness: A theoretical conjecture on the relationship between consumption, culture and subjective well-being at the national level. Journal of Happiness Studies, 3(1), 23-36.

Anderson, C. M., \& Martin, M. M. (1995). The effects of communication motives, interaction involvement, and loneliness on satisfaction: A model of small groups. Small Group Research, 26(1), 118-137.

Armstrong, M. (2003). Students as clients: A professional services model for business education. Academy of Management Learning and Education, 2(4), 371-374.

Athiyaman, A. (1997). Linking student satisfaction and service quality perceptions: The case of university education. European Journal of Marketing, 31(7), 528-540.

Banwet, D., \& Datta, B. (2003). A study of the effect of perceived lecture quality on post-lecture intentions. Work Study, 52(4/5), 234-243.

Bennett, R., \& Ali-Choudhury, R. (2009). Prospective students' perceptions of university brands: An empirical study. Journal of Marketing for Higher Education, 19(1), 85-107.

Berger, C., Blauth, R., Boger, D., Bolster, C., Burchill, G., DuMouchel, W., Pouliot, F., Richter, R., Rubinoff, A., Shen, D., Timko, M., \& Walden, D. (1993). Kano's methods for understanding customer-defined quality", The Centre for Quality Management Journal. 2 (4), 3-36.

Bhandari, M., Tsarenko, Y., \& Polonsky, M. (2007). A proposed multi-dimensional approach to evaluating service recovery. Journal of Services Marketing, 21(3), 174-185.

Bingham, F. B. (1987). Distribution and its relevance to educational marketing efforts. Journal of Professional Services Marketing, 2(4), 137-142.

Bitner, M., Booms, B., \& Tetreault, M. (1990). The service encounter: Diagnosing favorable and unfavorable incidents. Journal of Marketing, 54, 71-84.

Blodgett, J. G., Hill, D. J., \& Tax, S. S. (1997). The effects of distributive, procedural, and interactional justice on postcomplaint behaviour. Journal of Retailing, 73(2), 185-210.

Botschen, G., Thelen, E. M., \& Pieters, R. (1999). Using means-end structures for benefit segmentation. European Journal of Marketing, 33 (1/2), 38-58. 
Bove, L. L., \& Robertson, N. L. (2005). Exploring the role of relationship variables in predicting customer voice to a service worker. Journal of Retailing and Consumer Services, 12(2), 83-97.

Bove, L. L., Pervan, S. J., Beatty, S. E., \& Shiu, E. (2009). Service worker role in encouraging customer organizational citizenship behaviors. Journal of Business Research, 62(7), 698-705.

Bradley, G. L., \& Sparks, B. A. (2009). Dealing with service failures: The use of explanations. Journal of Travel and Tourism Marketing, 26(2), 129-143.

Browne, B., Kaldenberg, D., Browne, W., \& Brown, D. (1998). Student as customer: factors affecting satisfaction and assessments of institutional quality. Journal of Marketing for Higher Education, $8(3), 1-14$.

Chapleo, C. (2010). What Defines "Successful" University Brands? International Journal of Public Sector Management, 23(2), 169-183.

Cheetham, G., \& Chivers, G. (1998). The reflective (and competent) practitioner: A model of professional competence which seeks to harmonise the reflective practitioner and competencebased approaches. Journal of European Industrial Training, 22(7), 267-276.

Chen, C. C., Chen, X-P., \& Meindl, J. R. (1998). How can cooperation be fostered? The cultural effects of individualism-collectivism. The Academy of Management Review, 23(2), 285-304.

Chung, R., Bemak, F., \& Talleyrand, R. (2007). Mentoring within the field of counseling: A preliminary study of multicultural perspectives. International Journal for the Advancement of Counselling, 29(1), 21-32.

Corbyn, Z. (2009), "Biting the complaint bullet," (accessed August 11, 2009), [available at http://www.timeshighereducation.co.uk/story.asp?storycode=406809].

Cornelius-White, J. (2007). Learner-centered teacher-student relationships are effective: A metaanalysis. Review of Educational Research, 77(1), 113-143.

Cubillo, J., Sanchez, J., \& Cervino, J. (2006). International students' decision-making process. International Journal of Educational Management, 20(2), 101-115.

Curran, J. M., \& Rosen, D. E. (2006). Student attitudes toward college courses: An examination of influences and intentions. Journal of Marketing Education, 28 (2), 135-148.

Davis, J. C., \& Swanson, S. T. (2001). Navigating satisfactory and dissatisfactory classroom incidents. Journal of Education for Business, 76 (5), 245-250.

De Mooij, M. (2009), Global marketing and advertising: Understanding cultural paradoxes, $3^{\text {rd }}$ edition. London, UK: Sage Publications. 
Deeter-Schmelz, D. R., Goebel, D. J., \& Kennedy, K. N. (2008). What are the characteristics of an effective sales manager? An exploratory study comparing salesperson and sales manager perspectives. Journal of Personal Selling \& Sales Management, 28(1), 7-20.

Desai, S., Damewood, E., \& Jones, R. (2001). Be a good teacher and be seen as a good teacher. Journal of Marketing Education, 23 (2), 136-143.

Duffy, J., Miller, J., \& Bexley, J. (2006). Banking customers' varied reactions to service recovery strategies. International Journal of Bank Marketing, 24(2), 112-132.

Faranda, W. T., \& Clarke, I. (2004). Student observations of outstanding teaching: Implications for marketing education. Journal of Marketing Education, 26(3), 271-281.

Frankel, R., \& Swanson, S. R. (2002). The impact of faculty-student interactions on teaching behaviour: An investigation of perceived student encounter orientation, interactive confidence, and interactive practice. Journal of Education for Business, 78(2), 85-91.

Frankel, R., Swanson, S. R., \& Sagan, M. (2006). The role of individualism/collectivism in critical classroom encounters: A four country study. Journal of Teaching in International Business, 17(1), $33-59$.

Gengler, C. E., \& Reynolds, T. J. (1993). Laddermap: A Software Tool for Analyzing Laddering Data, Version 5.4 [Computer software].

Gengler, C. E., Klenosky, D. B. \& Mulvey, M. S. (1995). Improving the Graphic Representation of Means-End Results. International Journal of Research in Marketing. 12(3), 245-256.

Gengler, C. E., Mulvey, M. S., \& Oglethorpe, J. E. (1999). A means-end analysis of mothers' infant feeding choices. Journal of Public Policy \& Marketing, 18(2),172-88.

Granitz, N. A., Koernig, S. K., \& Harich, K. R. (2009). Now it's personal: Antecedents and outcomes of rapport between business faculty and their students. Journal of Marketing Education, 31(1), 5265.

Greenberg, J. (1987). The college sophomore as guinea pig: Setting the record straight. The Academy of Management Review, 12(1), 157-159.

Gremler, D. D., \& McCollough, M. A. (2002). Student Satisfaction Guarantees: An Empirical Examination of Attitudes, Antecedents, and Consequences. Journal of Marketing Education, 24(2), $150-160$

Gruber, T., Szmigin, I. \& Voss, R. (2006). The desired qualities of customer contact employees in complaint handling encounters. Journal of Marketing Management, 22, 5(6), 619-642. 
Gruber, T., Reppel, A., Szmigin, I., \& Voss, R. (2008), "Revealing the expectations and preferences of complaining customers by combining the laddering interviewing technique with the Kano model of customer satisfaction. Qualitative Market Research: An International Journal, 11 (4), 400-413.

Gruber, T., Szmigin, I., \& Voss, R. (2009). Developing a deeper understanding of attributes of effective customer contact employees in personal complaint handling encounters. Journal of Services Marketing, 23(6), 422-435.

Gutman, J. (1982). A means-end chain model based on consumer categorization processes. Journal of Marketing, 46 (Spring), 60-72.

Hall, E. T. (1976). Beyond culture. Garden City, NY: Anchor Books.

Harris, L. C., \& Ogbonna, E. (2010), "Hiding customer complaints: Studying the motivations and forms of service employees' complaint concealment behaviours. British Journal of Management, 21(2), 262-279.

Hart, C. W. L., Heskett, J. L., \& Sasser, E. W. (1990). The profitable art of service recovery. Harvard Business Review, 68 (July-August), 148-156.

Helgesen, Ø. (2008). Marketing for higher education: A relationship marketing approach. Journal of Marketing for Higher Education, 18(1), 50 - 78.

Hemsley-Brown, J., \& Oplatka, I. (2006). Universities in a competitive global marketplace: systematic review of the literature on higher education marketing. International Journal of Public Sector Management, 19 (4), 316-338.

Hemsley-Brown, J., \& Goonawardana, S. (2007). Brand harmonization in the international higher education market. Journal of Business Research, 60(9), 942-948.

Heslop, L. A., \& Nadeau, J. (2010). Branding MBA Programs: The Use of Target Market Desired Outcomes for Effective Brand Positioning. Journal of Marketing for Higher Education, 20(1), 85117.

Hofstede, G. (2001). Culture's consequences: Comparing values, behaviors, institutions, and organizations across nations, $2^{\text {nd }}$ edition. Thousand Oaks, CA: Sage.

Hofstede, G., \& Hofstede, G. J. (2005). Culture and organizations: Software of the mind, $2^{\text {nd }}$ edition. New York, NY: McGraw-Hill.

Hwarng, H. B., \& Teo, C. (2001). Translating Customers' Voices into Operations Requirements: A QFD Application in Higher Education. International Journal of Quality and Reliability Management, 18(2-3), 195-227. 
Ivy, J. (2001). Higher education institution image: A correspondence analysis approach. International Journal of Educational Management, 15(6), 276-282.

Iyer, R., \& Muncy, J. A. (2008). Service recovery in marketing education: It's what we do that counts. Journal of Marketing Education, 30 (1), 21-32.

Johnson, M. D., Herrmann, A., \& Huber, F. (2006). "The evolution of loyalty intentions. Journal of Marketing, 70 (April), 122-132.

Johnston, R., \& Michel, S. (2008). Three outcomes of service recovery: Customer recovery, process recovery and employee recovery. International Journal of Operations And Production Management, 28(1), 79-99.

Kano, N. (1984). Attractive quality and must be quality. Hinshitsu (Quality). 14(2), 147-156 (in Japanese).

Kano, N. (2001). Life cycle and creation of attractive quality. Paper presented at the 4th International QMOD Conference on Quality Management and Organisational Development, University of Linkoeping, Linkoeping, Sweden.

Kano, N. (2006). Attractive quality theory - Kano model. Paper presented at the 2006 Taipei Healthy Cities Leaders Roundtable and International Healthy Cities Conference, Taipei, Taiwan.

Kanousi, A. (2005). An empirical investigation of the role of culture on service recovery expectations. Managing Service Quality, 15(1), 57-69.

Karande, K., Magnini, V. P., \& Tam, L. (2007). Recovery voice and satisfaction after service failure: An experimental investigation of mediating and moderating factors. Journal of Service Research, 10(2), 187-203.

Kau, A., \& Loh, E. (2006). The effects of service recovery on consumer satisfaction: A comparison between complainants and non-complainants. Journal of Services Marketing, 20(2), 101-111.

Kennedy, M. S., Ferrell, L. K., \& Leclair, D. T. (2001). Consumers' trust of salesperson and manufacturer: An empirical study. Journal of Business Research, 51(1), 73-86.

Klayton, M. A. (1993). Using marketing research to improve university programs. Journal of Professional Services Marketing, 9(1), 105-114.

Lee, S. (2007). The relations between the student-teacher trust relationship and school success in the case of Korean middle schools. Educational Studies, 33(2), 209-216.

Lidén, S. B., \& Skålén, P. (2003). The Effect of Service Guarantees on Service Recovery. International Journal of Service Industry Management, 14(1), 36-58. 
Littlewood, W. (1999). Defining and developing autonomy in East Asian contexts. Applied Linguistics, 20(1), 71-94.

Littlewood, W. (2001). Students' attitudes to classroom English learning: A cross-cultural study. Language Teaching Research, 5(1), 3-28.

Löfgren, M., \& Witell, F. (2008). Two decades of using Kano's theory of attractive quality: A literature review. The Quality Management Journal, 15(1), 59-75.

Lowrie, A. (2007). Branding higher education: Equivalence and difference in developing identity. Journal of Business Research, 60(9), 990-999.

Maheswaran, D., \& Shavitt, S. (2000). Issues and new directions in global consumer psychology. Journal of Consumer Psychology, 9(2), 59-66.

Maringe, F. (2005). Interrogating the crisis in higher education marketing: The cord model. International Journal of Educational Management, 19(7), 564-578.

Markus, H., \& Kitayama, S. (1991). Culture and the self: Implications for cognition, emotion, and motivation. Psychological review, 98(2), 224-253.

Mattila, A. S. (1999). The role of culture in the service evaluation process. Journal of Service Research, 1(3), 250-261.

Mattila, A. S. (2001). The Effectiveness of service recovery in a multi-industry setting. Journal of Services Marketing, 15(7), 583-596.

Mattila, A. S. (2006). The power of explanations in mitigating the ill-effects of service failures. Journal of Services Marketing, 20(7), 422 - 428.

Mattila, A. S., \& Patterson, P. G. (2004a), "Service recovery and fairness perceptions in collectivist and individualist contexts. Journal of Service Research, 6(4), 336-346.

Mattila, A. S., \& Patterson, P. G. (2004b).The impact of culture on consumers' perceptions of service recovery efforts. Journal of Retailing, 80(3), 196-206.

Mattila, A. S., \& Wirtz, J. (2004). Consumer complaining to firms: The determinants of channel choice. Journal of Services Marketing, 18 (2), 147-155.

Matzler, K., Hinterhuber, H. H., Bailom, F., \& Sauerwein, E. (1996). How to delight your customers. Journal of Product \& Brand Management, 5 (2), 6-18.

Matzler, K., Bailom, F., Hinterhuber, H. H., Renzl, B., \& Pichler, J. (2004).The asymmetric relationship between attribute-level performance and overall customer satisfaction: A reconsideration of the importance-performance analysis. Industrial Marketing Management, 33 (4), 271-277. 
Maxham, J. G. (2001). Service recovery's influence on consumer satisfaction, positive word-of-mouth, and purchase intentions. Journal of Business Research, 54(1), 11-24.

Mazzarol, T., Soutar, G., \& Seng, M. (2003). The third wave: Future trends in international education. International Journal of Educational Management, 17(3), 90-99.

McColl-Kennedy, J. R., \& Sparks, B. A. (2003). Application of fairness theory to service failures and service recovery. Journal of Service Research, 5(3), 251-266.

McColl-Kennedy, J. R., Daus, C. S., \& Sparks, B. A. (2003). The role of gender in reactions to service failure and recovery. Journal of Service Research, 6(1), 66-82.

McCollough, M. A., \& Gremler, D. D. (1999). Guaranteeing student satisfaction: An exercise in treating students as customers. Journal of Marketing Education, 21(2), 118-130.

Michel, S. (2001). Analyzing service failures and recoveries: A process approach. International Journal of Service Industry Management, 12(1), 20-33.

Mount, D. J., \& Mattila, A. (2002). Last chance to listen: Listening behaviors and their effect on call center satisfaction. Journal of Hospitality and Tourism Research, 26(2), 124-137.

Mukherjee, A., Pinto, M. B., \& Malhotra, N. (2009), "Power perceptions and modes of complaining in higher education. The Service Industries Journal, 29(9), 1-23.

Mullen, M. R. (1995). Diagnosing measurement equivalence in cross-national research. Journal of International Business Studies, 26(3), 573-596.

Ng, S., Lee, J., \& Soutar, G. (2007). Are Hofstede's and Schwartz's value frameworks congruent? International Marketing Review, 24(2), 164-180.

Nilsson-Witell, L., \& Fundin, A. (2005). Dynamics of service attributes: A test of Kano's theory of attractive quality. International Journal of Service Industry Management, 16 (2), 152-168.

Nyer, P. (2000). An investigation into whether complaining can cause increased consumer satisfaction. Journal of Consumer Marketing, 17(1), 9-19.

Patterson, P., Romm, T., \& Hill, C. (1998). Consumer satisfaction as a process: A qualitative, retrospective longitudinal study of overseas students in Australia. Journal of Professional Services Marketing, 16(1), 135-157.

Paul, M., Hennig-Thurau, T., Gremler, D. D., Gwinner, K. P., \& Wiertz, C. (2009). Toward a theory of repeat purchase drivers for consumer services. Journal of the Academy of Marketing Science, 37(2), 215-37. 
Priporas, C. , \& Kamenidou, I. (2011). Perceptions of Potential Postgraduate Greek Business Students Towards Uk Universities, Brand and Brand Reputation. Journal of Brand Management, 18(4-5), 264-273.

Reynolds, T. J., \& Gutman, J. (1988). Laddering theory, method, analysis, and interpretation. Journal of Advertising Research, 28 (February/March), 11-31.

Reynolds, T. J., \& Olson, J. C. (2001). Understanding consumer decision making: the means-end approach to marketing and advertising strategy. Mahwah, NJ: Lawrence Erlbaum.

Ringberg, T., Odekerken-Schroder, G., \& Christensen, G. L. (2007). A cultural models approach to service recovery. Journal of Marketing, 71(3), 194-214.

Rokeach, M. (1973). The nature of human values. New York, NY: Free Press.

Schoefer, K., \& Diamantopoulos, A. (2008), "Measuring experienced emotions during service recovery encounters: construction and assessment of the e s r e scale. Service Business, 2(1), 65-81.

Schwartz, S. (1994). Beyond individualism/collectivism: New cultural dimensions of values. In U. Kim, H.C. Triandis, C. Kagitcibasi, S. C Choi, \& G. Yoon (Eds.), Individualism and collectivism: Theory, method, and applications (pp. 85-119). London: Sage

Schwiebert, V. L. (2000). Mentoring: Creating connected, empowered relationships. Alexandria, VA: American Counseling Association.

Scott, S. (1999). The academic as service provider: Is the customer 'always right? Journal of Higher Education Policy and Management, 21(2), 193-202.

Seawright, K., Detienne, K., Bernhisel, M., \& Larson, C. (2008). An empirical examination of service recovery design. Marketing Intelligence and Planning, 26(3), 253-274.

Smith, A. K., Bolton, R. N., \& Wagner, J. (1999). A model of customer satisfaction with service encounters involving failure and recovery. Journal of Marketing Research, 36(3), 356-372.

Soares, A. M., Farhangmehr, M., \& Shoham, A. (2007). Hofstede's dimensions of culture in international marketing studies. Journal of Business Research, 60(3), 277-284.

Sohail, M., \& Shaikh, N. (2004). Quest for excellence in business education: a study of student impressions of service quality. International Journal of Educational Management, 18(1), 58-65.

Steenkamp, J-B. E. M., Hofstede, F. T., \&. Wedel, M. (1999). A cross-national investigation into the individual and national cultural antecedents of consumer innovativeness. Journal of Marketing, 63 (April), 55-69.

Steenkamp, J-B. E. M. (2001). The role of national culture in international marketing research. International Marketing Review, 18(1), 30-44. 
Stewart, K. L. (1991). Applying a marketing orientation to a higher education setting. Journal of Professional Services Marketing, 7(2), 117-124.

Straus, M. A. (2009). The national context effect: an empirical test of the validity of cross-national research using unrepresentative samples. Cross-Cultural Research, 43(3), 183-205.

Swan, J. E., Bowers, M. R., \& Richardson, L. D. (1999). Customer trust in the salesperson: An integrative review and meta-analysis of the empirical literature. Journal of Business Research, 44(2), 93-107.

Swanson, S. R., \& Davis, J. C. (2000). A view from the aisle: Classroom successes, failures and recovery strategies. Marketing Education Review, 10(2), 17-26.

Swanson, S. R., Frankel, R., \& Sagan, M. (2005). Classroom encounters: Exploring the impact of cultural differences. Marketing Education Review, 15(3), 37-48.

Szmigin, I., \& Reppel, A. E. (2004). Internet community bonding: The case of Macnews.de. European Journal of Marketing, 38 (5/6), 626-40.

Tax, S. S., \& Brown, S. W. (1998). Recovering and learning from service failure. Sloan Management Review, 40(1), 75-88.

Tax, S. S., Brown, S. W., \& Chandrashekaran, M. (1998). Customer evaluations of service complaint experiences: Implications for relationship marketing. Journal of Marketing, 62 (April), 60-76.

Thompson, D. V., Hamilton, R. W., \& Rust, R. T. (2005). Feature fatigue: When product capabilities become too much of a good thing. Journal of Marketing Research, 42 (November), 431-442.

Voss, R. (2009). Studying critical classroom encounters: The experiences of students in German college education. Quality Assurance in Education, 17(2), 156-173.

Voss, R., \& Gruber, T. (2006). The desired teaching qualities of lecturers in higher education: A means end analysis. Quality Assurance in Education, 14(3), 217-242.

Voss, R., Gruber, T., \& Szmigin, I. (2007). Service quality in higher education: The role of student expectations. Journal of Business Research, 60 (9), 949-959.

Wæraas, A., \& Solbakk, M. N. (2009). Defining the Essence of a University: Lessons from Higher Education Branding. Higher Education, 57(4), 449-462.

Winsted, K. F. (1997). The service experience in two cultures: A behavioral perspective. Journal of Retailing, 73(3), 337-360.

Wiseman, R. L. (2002). Intercultural communication competence. In W. Gudykunst, \& B. Mody (Eds.), Handbook of international and intercultural communication (pp. 207-219), London: Sage Publications. 
Yuksel, A. (2008). Nonverbal service behavior and customer's affective assessment. Journal of Quality Assurance in Hospitality and Tourism, 9(1), 57-77.

Zanoli, R., \& Naspetti, S. (2002). Consumer motivations in the purchase of organic food - A meansend approach. British Food Journal, 104(8), 643-653.

Zeithaml, V. A, Bitner, M. J., \& Gremler, D. D. (2006). Services marketing, $4^{\text {th }}$ edition. Singapore: McGraw-Hill Education (Asia).

Zemke, R., \& Bell, C. R. (1990). Service recovery: Doing it right the second time. Training, 27(6), 4248.

Zemke, R., \& Bell, C. R. (2000). Knock your socks off service recovery. New York, NY: AMACOM Division American Management Association.

Zhang, Q., \& Oetzel, J. (2006). A cross-cultural test of immediacy-learning models in Chinese classrooms. Communication Education, 55(3), 313-330.

Zhang, J., Beatty, S. E., \& Walsh, G. (2008). Review and future directions of cross-cultural consumer services research. Journal of Business Research, 61(3), 211-224 